\title{
Inventory and Monitoring of Bald Eagles and Other Raptorial Birds of the Snake River, Idaho
}

\section{6-1997 Progress Report}

prepared by

Michael B. Whitfield

Mary E. Maj

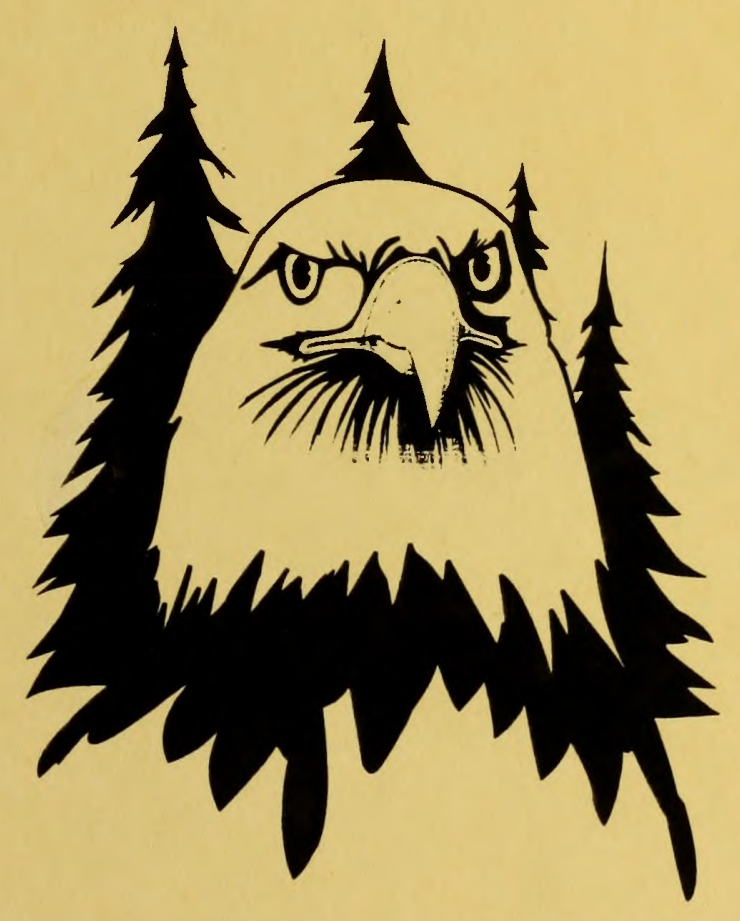

QL

84.2

.5352

no.

98-2

USDI Bureau of Land Management and

Northern Rockies Conservation Cooperative 
, 


\title{
INVENTORY AND MONITORING OF BALD EAGLES AND OTHER RAPTORIAL BIRDS OF THE SNAKE RIVER, IDAHO
}

1996-97 PROGRESS REPORT

\author{
Prepared by \\ Michael B. Whitfield \\ Mary E. Maj
}

U.S.D.I Bureau of Land Management
and
Northern Rockies Conservation Cooperative

December, 1997 



\section{INVENTORY AND MONITORING OF BALD EAGLES AND OTHER RAPTORIAL BIRDS OF THE SNAKE RIVER, IDAHO}

\section{6-97 PROGRESS REPORT}

Michael B. Whitfield, Research Associate, Northern Rockies Conservation Cooperative, Jackson, Wyoming, and P. O. Box 241, Tetonia, Idaho 83452

Mary E. Maj, Wildlife Biologist, Native Land Ecology, P. O. Box 263, Tetonia, Idaho 83452

\section{Executive Summary}

The Snake River Bald Eagle and Raptor Project, a five-year effort, was initiated in 1994 with two primary objectives: 1 ) to monitor bald eagle productivity in Southeast Idaho, and 2) to develop a monitoring program for raptorial birds in the Snake River study area. The South Fork Snake River study area in Southeast Idaho, including the lower Henry's Fork, is recognized for its highly productive bald eagle breeding pairs and diversity of raptors. Herein, we report progress for the 1996 and 1997 field seasons.

In 1996, there were 45 known bald eagle breeding areas within the Southeast Idaho portion of the Greater Yellowstone Ecosystem. Three new breeding areas were located in 1996: Clark's Hill (18-IS-25) on the South Fork, Ririe Reservoir (18-IS-26), and Annis Slough (18-IS-27) at the Confluence of the South Fork and Henry's Fork Snake River. In total, 43 of 45 nests were occupied, 39 were active, and 27 were successful, with 42 advanced young produced. Outcome was unknown at 1 site. The average ratio of advanced young/occupied nest with known outcome was 1.00 .

In 1997, we report results of activity and productivity surveys at each of 47 known bald eagle breeding areas. The two additional breeding areas arose from reevaluation of nesting behavior at nest sites on Palisades Reservoir. In 1997, 42 of 45 breeding areas where outcome was known were occupied, 37 areas were active, 27 areas were successful, and 46 advanced young were produced. Outcome was unkown at 2 sites. The average ratio of advanced young/occupied nest with known outcome was 1.10.

In 1994-95, we analyzed raptor macro-habitat selectivity through presence/absence surveys. In 1996-97, we further clarified raptor habitat selection through more specific description of micro-habitat features in occupied areas.

Even though young bald eagle pairs are occupying new breeding areas, we are witnessing the gradual loss of historically productive bald eagle nesting areas, primarily on private lands that are now being developed. This is most apparent in the South Fork reach from Palisades Dam to Conant Valley, and highlights the importance of protected habitats. We have also documented the high value of riparian cottonwood forests and nearby Douglas fir forests for many other nesting birds of prey. 


\section{Introduction}

This progress report documents the third and fourth years of a five-year project to monitor raptorial birds within the Snake River ecosystem of southeastern Idaho. The project goal is to develop monitoring tools that can be applied to conservation at several levels: nesting bald eagle productivity, raptorial birds as a guild or trophic level, and biological communities generally (see discussion in Whitfield et al. 1995).

\section{Objectives}

I. Determine bald eagle productivity and document habitat observations for bald eagle breeding areas within the Idaho portion of the Greater Yellowstone Ecosystem. Specific 1996-1997 tasks within this objective are:

a. Complete bald eagle nesting area surveys for each breeding area.

b. Monitor and assess the effects of human disturbance to each breeding area as noted during activity and productivity surveys.

c. In 1996, provide preliminary identification of key habitat use areas for the following bald eagle breeding areas: Kerr Canyon (18-IC-01) and Hale Canyon (18-IC-10).

d. In 1997, provide preliminary identification of key habitat use areas for the following bald eagle breeding areas: Five Ways (18-IS-24) and Clark Hill (18-IS-25).

II. An overall goal of this five-year project is to develop an inventory and monitoring program for all raptorial birds of the Snake River study area (Species listed in Table 1). In 1996-97, we completed the following objectives:

a. Refine descriptions of nesting habitats within identified raptor nesting areas through examination of micro-habitat features within identified nesting areas.

b. Provide a synthesis of literature on recreation effects upon raptor habitat use.

\section{Study Area}

The 119 mile reach of Snake River corridor identified in the BLM and Forest Service 1991 Snake River Activity/Operations Plan is the core of the study area (figure 1). This area includes the South Fork Snake River from Palisades Dam beyond the confluence to Market Lake Canal, and Henry's Fork from St. Anthony to its confluence with the mainstem Snake. The study area is expanded to include upland habitats within 1 mile on each side of the river. In preliminary studies, the investigators located breeding raptors which nest within this expanded area and rely in part upon the riparian bottom for foraging habitat.

The upper section of the South Fork below Palisades Dam flows through a mountain valley, Swan Valley, Idaho. It then flows into a rugged, deeply incised canyon approximately 26 miles in length. The lower South Fork and the Henry's Fork below St. Anthony meander across broad, braided flood plains. Most of the South Fork in these lower reaches is contained by a dike system. 
The South Fork Snake River is bordered by cottonwood gallery forests recognized as among the largest and most intact in the western United States. Beyond the floodplain, landscapes on each side of the river include a rich diversity of vegetative cover and topographic relief: conifer and aspen covered foothills, park-like pasturelands and cultivated crop lands; precipitous canyon walls; sage, mountain mahogany, and juniper covered slopes; and steep, rocky mountains. The lower reaches feature biologically rich sloughs and wetlands. The South Fork and lower reach of the Henry's Fork are recognized as a primary biological asset of the Greater Yellowstone Ecosystem , primarily because of the diversity of species supported within the cottonwood forests.

Bald eagles are monitored within a larger region, the Idaho portion of the Greater Yellowstone Ecosystem (GYE). This area includes Southeast Idaho west to Interstate 15 from the Montana border to Idaho Falls, and the Snake River watershed south to the Wyoming border at the upper end of Palisades Reservoir. This larger region includes the Snake River study area plus the upper Henry's Fork in Island Park, outlying lakes like Sheridan Reservoir, and Henry's Fork tributaries such as the Falls and Teton River watersheds.

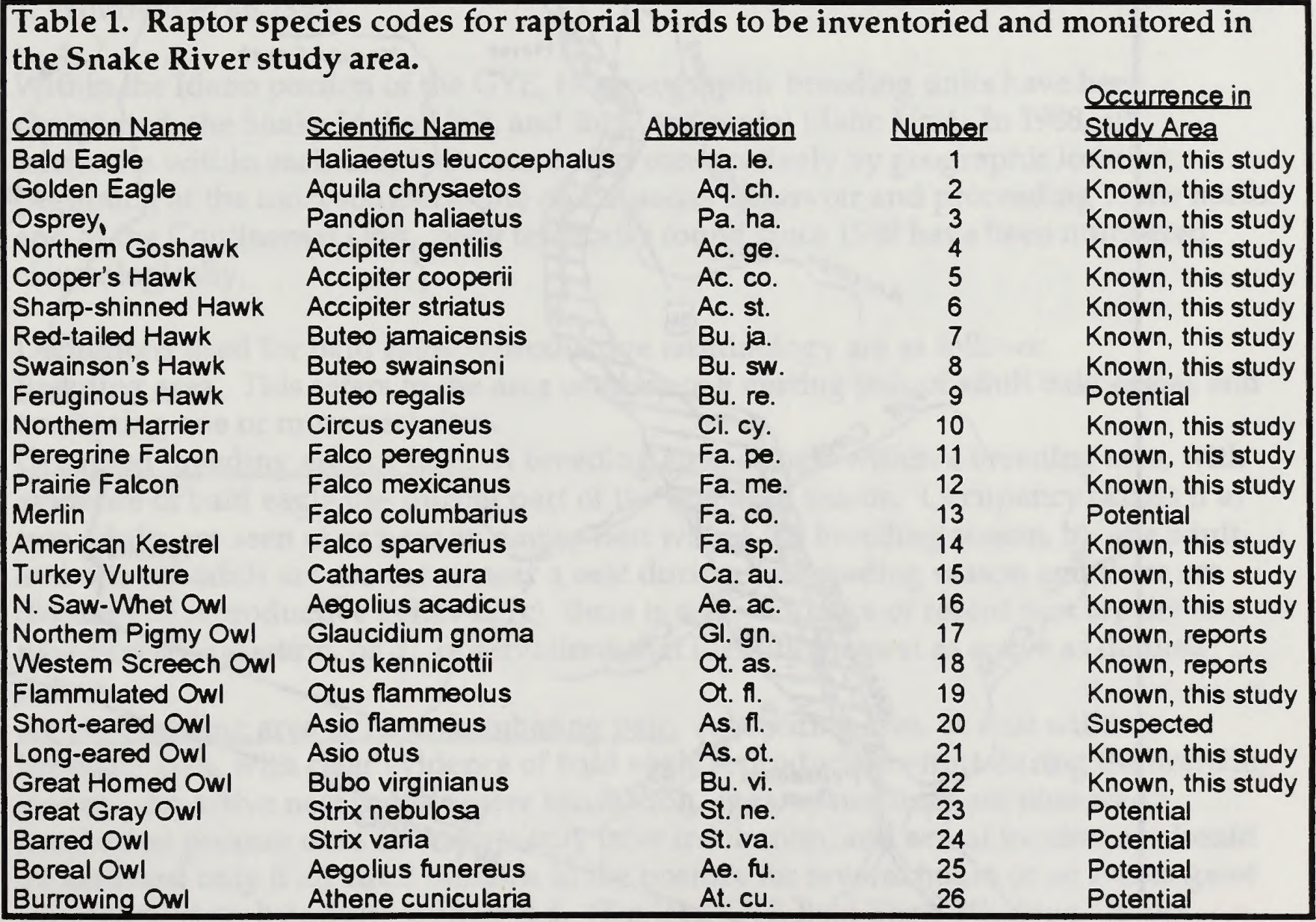




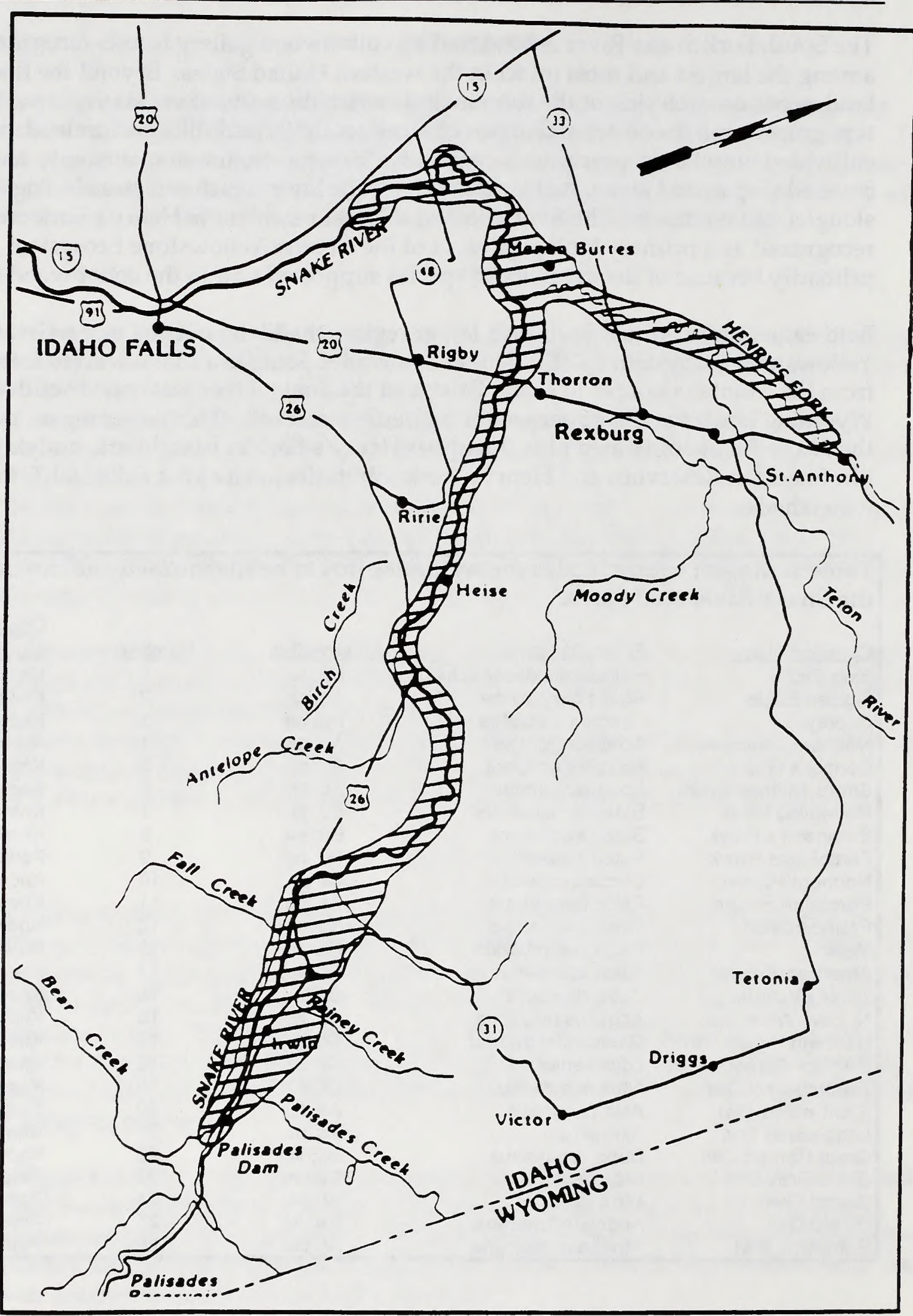

Figure 1. Snake River study area. This map is taken trom the Snake River Activity/Operations Plan (L'SDI BL.M and LSDA Forest Service 1991). Scale $1: 500,000$ 


\section{Methods}

\section{Bald Eagle Productivity Monitoring}

All known and suspected bald eagle breeding areas are surveyed to collect the following data: nest occupancy, breeding activity, breeding success, and number of advanced young produced. All nest sites are visited a minimum of twice: early for an activity (incubation) check and later for a productivity check. In most cases, additional activity checks are necessary to more clearly document activity or to locate new alternate nest sites. Nesting chronology is monitored where reliable data can be obtained.

Activity checks are completed by a combination of aerial and ground or boat surveys. Most early ground checks are from long distance with spotting scopes to avoid disturbance to adults. Later visits are made to measure productivity at active nest sites. Nestlings are banded during this visit where nest trees can be safely climbed. Our experience of 17 years of monitoring bald eagle nesting activity and productivity in this region suggests an area-specific strategy for bald eagle monitoring (see Appendix Table 1, Whitfield et al. 1995).

Within the Idaho portion of the GYE, two geographic breeding units have been designated, the Snake Idaho Unit, and the Continental Idaho Unit. In 1988, all territories within each unit were numbered consecutively by geographic location, beginning at the most southerly site on Palisades Reservoir and proceeding to the north end of the Continental Unit. New territories found since 1988 have been numbered chronologically.

Definitions used for bald eagle reproductive terminology are as follows:

Breeding area. This refers to the area used by one nesting pair of adult bald eagles and containing one or more nest sites.

Occupied breeding area or nest. A breeding area, or nest within a breeding area, with evidence of bald eagle use during part of the breeding season. Occupancy occurs if a) two adults are seen at or near an empty nest within the breeding season, b) one adult and one subadult are seen at or near a nest during the breeding season and there are displays of reproductive behavior, $c$ ) there is clear evidence of recent nest repairs or new nest construction, or d) observations that identify the nest as active as defined below.

Active breeding area or nest. Incubating pair. A breeding area, or nest within a breeding area, with clear evidence of bald eagle reproductive effort during the breeding season. An active nest is one where incubation, eggs, or nestlings are observed. Incubation posture does not necessarily infer incubation, and actual incubation should be assumed only if an adult remains in the posture for several hours or an exchange of incubation duty by adults is observed. (Revised GYE Bald Eagle Working Group guidelines substitute Active with the term "Incubating Pair".) 
Successful breeding area or nest. A breeding area, or nest within a breeding area, where advanced young are produced. Advanced young are young of the year at or near fledging age.

\section{Bald Eagle Breeding Area Key Habitat Identification}

At selected bald eagle breeding areas, breeding adult and nestling behavior are monitored to learn area specific habitat needs. In earlier years, this monitoring effort was much more intensive, with radio telemetry sometimes used to aid observations (Whitfield et al. 1991, Whitfield 1993). For this project, our observations are limited to approximately 6 observation periods ( 4 hours each) at each breeding area during the nesting season to provide preliminary delineation of primary use areas, nest site management zone II (GYE Bald Eagle Working Group 1995). These preliminary observations are typically centered at the nest site, and do not provide a complete picture of a breeding pair's habitat use. Observers monitor from a distance with spotting scopes.

\section{Raptor Monitoring Program}

Our raptor inventory is iterative over the five years of the project, with an additive progression through phases as the data is collected and analyzed. We include here a summary of the methods to be used over the life of the project to provide perspective for each year's work (see Whitfield et al. 1995). Sampling methods, including raptor species detection and estimation of relative abundance and breeding productivity, must be species specific. Once our inventory has provided a reliable baseline, we will develop a long-term monitoring program for the raptors of the South Fork study area.

Breeding Raptor Detection.

We apply species-specific raptor detection methods. We provided a literature review of raptor detection methods in Whitfield et al. 1995. We will also analyze detectability models from a statistical perspective as the project progresses.

\section{Raptor Inventory.}

Our raptor inventory occurs in two phases as follows:

Phase 1. Presence/Absence Sampling. Sample sites are selected to cover a broad array of biological and physical attributes; such coverage will help assure adequate representation of species composition and distribution over the study area. Sampling must be exhaustive enough to minimize under-sampling effects on patterns while allowing true patterns or gradients across the study area to be identified, described and predicted. With respect to monitoring, sampling must also ensure that study-wide trends and change can be distinguished from localized fluctuations (McKenzie et al. 1991). Hence the number, placement, and size of the sample sites will require careful consideration from both the biological and statistical perspectives. 
In 1995-96, we entered all potential samples, all square mile sections within the study area, into a Latin Square table with samples containing similar habitats grouped within the table. We then randomly selected samples according to a Latin Square plus 1 design. We used mapped legal sections because there are often section markers on the ground that aid in sample location. We selected from all square mile sections that were at least $50 \%$ within 1 mile of the river. We then individually sampled all 40 -acre quadrats (16 per square mile section) within selected sections.

In 1996-97, we deviated from our intended schedule to learn more habitat specificity for nesting habitat selection. We sampled from a larger sample group than visited in 1995, and described more specific vegetative features than described earlier.

Habitat description

For Phase 1 surveys (presence/absence) completed in 1995 and reported in Whitfield and Maj, 1996, we characterized each 40 acre sample quadrat by general vegetation cover type according to the system developed by Ulliman et al. (1991), which includes 30 cover types (Table 2, Whitfield and Maj 1996). We indicated the dominant cover type found within each quadrat, with recognition that many quadrats feature a complex mosaic of vegetative cover types (Appendix Table 5, Whitfield and Maj 1996).

In 1996-97, our habitat measures were more refined to characterize features selected by individual raptor species. As this project matures, we hope to characterize, at a landscape level, habitat features found within areas estimated to include the home ranges of nesting raptor pairs. We will also measure habitat features around all nest sites to determine those features of importance to nest occupancy and success.

\section{Results and Discussion}

\section{1996 Bald Eagle Nesting Activity and Productivity}

In 1996, 45 bald eagle breeding areas were known within the Southeast Idaho portion of the Greater Yellowstone Ecosystem (GYE). Of this total, 27 were found within the Snake Idaho Unit of the GYE population, and 18 in the Continental Idaho Unit (Table 2). Overall, the ratio of young produced per occupied breeding area (outcome known) was 1.00. Results of activity and productivity surveys at each breeding area were reported earlier (Whitfield et al. 1996).

Despite a wet 1996 spring, bald eagle productivity at Idaho sites was relatively good. All 27 known breeding areas in the Snake Idaho unit were occupied, and 25 of these breeding areas were active. (Productivity outcome was unknown at the new site on Ririe Reservoir. This area was excluded from ratios.) In the Snake Idaho population unit, a total of 27 young were produced at 16 successful sites, for productivity ratios of 
1.04 advanced young/occupied site, 1.12 advanced young/active site, and 1.69 advanced young/successful site.

In the Continental Idaho unit, 16 of 18 known breeding areas were occupied, and 14 were active. Fifteen young were produced at the 11 successful sites, for productivity ratios of 0.94 advanced young/occupied site, 1.07 advanced young/active site, and 1.36 advanced young/successful site.

Three new breeding areas were located in 1996: Clark's Hill (18-IS-25) on the South Fork, Ririe Reservoir (18-IS-26), and Annis Slough (18-IS-27) near the Confluence of the South Fork and Henry's Fork Snake River. Six established pairs built new alternate nests, and two pairs switched to alternate nests used prior to last year.

In 1996 we observed 6 nesting adults that were banded as nestlings in the GYE, and determined the natal nest of 3 of these adults. We also saw two immature bald eagles that were banded at known Idaho sites in prior years. In 1996, 16 Idaho/GYE nestlings were banded with numbered FWS leg bands on the right leg and color bands with stamped two digit alphanumeric codes on the left leg.

Table 2. Activity and productivity status for bald eagle breeding territories within the Idaho portion of the Greater Yellowstone Ecosystem, 1996.

\begin{tabular}{|c|c|c|c|c|c|}
\hline $\begin{array}{l}\text { TERRITORY } \\
\text { NAME }\end{array}$ & $\begin{array}{l}\text { TERRITORY } \\
\text { NUMBER }\end{array}$ & $\begin{array}{l}\text { PRODUCTIVITY } \\
\text { STATUS }\end{array}$ & $\begin{array}{l}\text { NUMBER } \\
\text { ADVANCED } \\
\text { YOUNG }\end{array}$ & $\begin{array}{l}\text { NUMBER } \\
\text { YOUNG } \\
\text { BANDED }\end{array}$ & COMMENTS \\
\hline \multicolumn{6}{|c|}{ PALISADES RESERVOIR AREA } \\
\hline Hoffman & $18-1 S-01$ & Active, Successful & 2 & 0 & New alt. nest \\
\hline Williams Creek & $18-1 S-02$ & Active, Successful & 2 & 2 & \\
\hline Van Point & $18-15-03$ & Active, Unsuccessful & 0 & 0 & \\
\hline Edwards Creek & $18-1 S-17$ & Active, Unsuccessful & 0 & 0 & \\
\hline King Creek & $18-1 S-18$ & Active, Unsuccessful & 0 & 0 & \\
\hline \multicolumn{6}{|c|}{ SOUTH FORK SNAKE RIVER } \\
\hline Palisades Creek & $18-15-04$ & Occupied, Inactive & 0 & 0 & $\begin{array}{l}\text { Nest repaired, did not } \\
\text { incubate }\end{array}$ \\
\hline Swan Valley & $18-1 S-05$ & Active, Successful & 1 & 0 & \\
\hline Conant Valley & $18-1 S-06$ & Active, Successful & 2 & 0 & Moved back to alt. 3 \\
\hline Pine Creek & $18-1 S-07$ & Occupied, Inactive & 0 & 0 & Nests repaired, no inc. \\
\hline Dry Canyon & $18-1 S-08$ & Active, Successful & 1 & 0 & \\
\hline Gormer Canyon & $18-15-09$ & Active, Successful & 2 & 2 & \\
\hline
\end{tabular}


Table 2. Activity and productivity status for bald eagle breeding territories within the Idaho portion of the Greater Yellowstone Ecosystem, 1996 (cont.).

\begin{tabular}{|c|c|c|c|c|c|}
\hline $\begin{array}{l}\text { TERRITORY } \\
\text { NAME }\end{array}$ & $\begin{array}{l}\text { TERRITORY } \\
\text { NUMBEB }\end{array}$ & $\begin{array}{l}\text { PRODUCTIVITY } \\
\text { STATUS }\end{array}$ & $\begin{array}{l}\text { NUMBER } \\
\text { ADVANCED } \\
\text { YOUNG }\end{array}$ & $\begin{array}{l}\text { NUMBER } \\
\text { YOUNG } \\
\text { BANDED }\end{array}$ & COMMENTS \\
\hline Wolverine & $18-1 S-10$ & Active, Successful & 1 & 0 & Moved back to alt. 1 \\
\hline Antelope Creek & $18-\mid S-11$ & Active, Unsuccessful & 0 & 0 & \\
\hline Cress Creek & $18-\mid S-12$ & Active, Successful & 2 & 0 & \\
\hline Five Ways & $18-I S-24$ & Active, Successful & 2 & 0 & \\
\hline Clark Hill & $18-1 S-25$ & Active, Successful & 2 & 0 & New breeding area \\
\hline
\end{tabular}

MAIN SNAKE RIVER

$\begin{array}{lllll}\text { Confluence } & 18-1 S-13 & \text { Active, Unsuccesstul } & 0 & 0 \\ \text { Market Lake } & 18-I S-22 & \text { Active, Successful } & 1 & 0\end{array}$

LOWER SOUTH FORK, HENRY'S FORK, FALL RIVER

\begin{tabular}{|c|c|c|c|c|c|}
\hline Menan Buttes & $18-1 S-20$ & Active, Unsuccessful & 0 & 0 & Nest blowdown \\
\hline Ririe Reservoir & $18-I S-26$ & Active, Unknown & $?$ & 0 & New, prod. unknown \\
\hline Annis Slough & $18-I S-27$ & Active, Successful & 1 & 0 & New breeding area \\
\hline Cartier Slough & $18-1 S-14$ & Active, Unsuccessful & 0 & 0 & \\
\hline St. Anthony & $18-1 S-15$ & Active, Successful & 2 & 0 & New alt. nest \\
\hline Singleton & $18-15-16$ & Active, Successful & 2 & 0 & \\
\hline Lower Fall River & $18-15-19$ & Active, Unsuccessful & 0 & 0 & New alt., blowdown. \\
\hline \multicolumn{6}{|c|}{ TETON RIVER, SNAKE UNIT } \\
\hline Upper Teton & $18-\mid S-21$ & Active, Successful & 2 & 0 & \\
\hline Hog Hollow & $18-1 S-23$ & Active, Successful & 2 & 0 & \\
\hline \multicolumn{6}{|c|}{ CONTINENTAL UNIT, UPPER HENRY'S FORK SNAKE RIVER } \\
\hline Kerr Canyon & $18-\mid C-01$ & Active, Successful & 1 & 1 & \\
\hline Pine Haven & $18-I C-02$ & Occupied, Inactive & 0 & 0 & \\
\hline Box Canyon & $18-I C-03$ & Active, Unsuccessful & 0 & 0 & \\
\hline Coffee Pot & $18-I C-04$ & Active, Successful & 1 & 1 & New alt. nest \\
\hline Bishop Lake & $18-I C-05$ & Active, Successful & 1 & 1 & \\
\hline Sheridan & $18-I C-06$ & Occupied, Inactive & 0 & 0 & \\
\hline
\end{tabular}


Table 2. Activity and productivity status for bald eagle breeding territories within the Idaho portion of the Greater Yellowstone Ecosystem, 1996 (cont.).

\begin{tabular}{|c|c|c|c|c|c|}
\hline $\begin{array}{l}\text { TERRITORY } \\
\text { NAME }\end{array}$ & $\begin{array}{l}\text { TERRITORY } \\
\text { NUMBEB }\end{array}$ & $\begin{array}{l}\text { PRODUCTIVITY } \\
\text { STATUS }\end{array}$ & $\begin{array}{l}\text { NUMBER } \\
\text { ADVANCED } \\
\text { YQUNG }\end{array}$ & $\begin{array}{l}\text { NUMBER } \\
\text { YOUNG } \\
\text { BANDED }\end{array}$ & COMMENTS \\
\hline Lucky Dog & $18-1 C-07$ & Active, Unsuccessful & 0 & 0 & \\
\hline Henry's Lake & $18-I C-08$ & Unoccupied & 0 & 0 & \\
\hline $\begin{array}{l}\text { Staley Springs- } \\
\text { Targhee Creek }\end{array}$ & $18-I C-09$ & Active, Successful & 1 & 0 & \\
\hline Hale Canyon & $18-1 C-10$ & Active, Successful & 2 & 2 & \\
\hline Moonshine & $18-\mid C-11$ & Active, Successful & 1 & 1 & \\
\hline Last Chance & $18-I C-12$ & Active, Successful & 2 & 2 & \\
\hline IP Bills & $18-\mid C-13$ & Active, Successful & 1 & 0 & New att. nest \\
\hline Flat Rock & $18-I C-14$ & Active, Successful & 2 & 2 & \\
\hline Riverside & $18-I C-15$ & Active, Successful & 2 & 2 & \\
\hline Snake River Butte & $18-1 C-16$ & Active, Successful & 1 & 0 & New alt. nest \\
\hline Buffalo River & $18-\mid C-17$ & Unoccupied & 0 & 0 & \\
\hline Big Bend & $18-I C-18$ & Active, Unsuccessful & 0 & 0 & \\
\hline
\end{tabular}

\section{Summary Statistics:}

Total number nesting territories: 45

Advanced young/occupied nest ${ }^{1}: 1.00$

Number occupied territories: 43

Number active territories: 39

Advanced young/active nest ${ }^{1}: 1.11$

Number successful territories: 27

Number advanced young: 42

Advanced young/successful nest ${ }^{1}: 1.56$

1 Excludes Ririe Reservoir, 18-IS-26, an active nesting area where productivity outcome was unknown. 


\section{1997 Bald Eagle Nesting Activity and Productivity}

In 1997, we completed activity and productivity surveys at 46 of the 47 known bald eagle breeding areas within the Southeast Idaho portion of the Greater Yellowstone Ecosystem (GYE). The two additional breeding areas over those reported in 1996 arose from reevaluation of nesting behavior at nest sites on Palisades Reservoir. Overall, the ratio of young produced per occupied breeding area (outcome known) was 1.10. Results of activity and productivity surveys at each breeding area were reported earlier (Whitfield et al. 1997).

In 1997, despite another wet spring, bald eagle productivity at Idaho sites was relatively good at lower elevations. Of 29 known breeding areas in the Snake Idaho unit, 26 were occupied and 24 were active. (Activity and productivity outcome were unknown at the site on Ririe Reservoir. Cartier Slough was active, but success was unknown. These areas were excluded from ratios.) In the Snake Idaho population unit, for sites with known productivity, a total of 33 young were produced at 25 occupied, 23 active, and 20 successful sites, for productivity ratios of 1.32 advanced young/occupied site, 1.43 advanced young/active site, and 1.65 advanced young/successful site. (Some advanced young at lower river nest sites may not have survived extremely high flood water in later June; it was not possible to observe these sites immediately post-fledging.)

In the Continental Idaho unit, 17 of 18 known breeding areas were occupied, and 14 were active. Thirteen young were produced at 7 successful sites, for productivity ratios of 0.76 advanced young/occupied site, 0.93 advanced young/active site, and 1.86 advanced young/successful site.

Two bald eagle pairs nested in sites that forced reanalysis of breeding area status for prior years. On Palisades Reservoir, two separate pairs nested in what had formerly been reported as alternate nests for the Hoffman breeding area. A similar event occurred at Van Point. Nine established pairs built new alternate nests, and three pairs switched to alternate nests used prior to last year. Two of these alternates, within the general area of the Confluence and Riverside breeding areas, may actually be new pairs.

In 1997 we observed 3 banded adults, 2 banded as nestlings and 1 as an adult in GYE/Idaho. In 1997, 15 nestlings were banded with numbered FWS leg bands on the right leg and color bands with stamped two digit alphanumeric codes on the left leg. 
Table 3. Activity and productivity status for bald eagle breeding territories within the Idaho portion of the Greater Yellowstone Ecosystem, 1997.

\begin{tabular}{lllll} 
& & & NUMBER & NUMBER \\
TERRITORY & TERRITORY & PRODUCTIVITY & ADVANCED YOUNG \\
NAME & NUMBER & STATUS & YOUNG & BANDED \\
\hline
\end{tabular}

PALISADES RESERVOIR AREA

\begin{tabular}{|c|c|c|c|c|c|}
\hline Hoffman & $18-I S-01$ & Active, Successful & 1 & 1 & \\
\hline Hoffman West & $18-1 S-28$ & Active, Successful & 2 & 2 & $\begin{array}{l}\text { New territory or King } \\
\text { Creek alternate. }\end{array}$ \\
\hline Williams Creek & $18-15-02$ & Occupied, inactive & 0 & 0 & \\
\hline Van Point & $18-15-03$ & Active, Successful & 1 & 0 & \\
\hline Van Point South & $18-1 S-29$ & Active, Successful & 1 & 1 & $\begin{array}{l}\text { New territory or } \\
\text { Edwards Cr. alternate. }\end{array}$ \\
\hline Edwards Creek & $18-1 S-17$ & Unoccupied & 0 & 0 & \\
\hline King Creek & $18-1 S-18$ & Unoccupied & 0 & 0 & \\
\hline $\begin{array}{l}\text { SOUTH FORK } \\
\text { Palisades Creek }\end{array}$ & $\begin{array}{l}\text { SNAKE R } \\
18-1 S-04\end{array}$ & Active, Unsuccessful & 0 & 0 & \\
\hline Swan Valley & $18-1 S-05$ & Occupied, Inactive & 0 & 0 & \\
\hline Conant Valley & $18-1 S-06$ & Active, Successful & 2 & 0 & 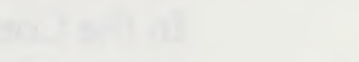 \\
\hline Pine Creek & $18-15-07$ & Active, Successful & 1 & 0 & \\
\hline Dry Canyon & $18-1 S-08$ & Active, Unsuccessful & 0 & 0 & 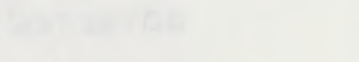 \\
\hline Gormer Canyon & $18-15-09$ & Active, Successful & 3 & 3 & \\
\hline Wolverine & $18-1 S-10$ & Active, Successful & 2 & 0 & \\
\hline Antelope Creek & $18-15-11$ & Active, Successful & 1 & 0 & \\
\hline Cress Creek & $18-1 S-12$ & Active, Successful & 2 & 0 & \\
\hline Five Ways & $18-I S-24$ & Active, Successful & 2 & 0 & \\
\hline Clark Hill & $18-1 S-25$ & Active, Successful & 1 & 0 & $\begin{array}{l}1 \text { advanced nestling } \\
\text { died at fledging. }\end{array}$ \\
\hline \multicolumn{5}{|c|}{ MAIN SNAKE RIVER } & New alt., Dry Bed \\
\hline Market Lake & $18-1 S-22$ & Active, Successful & 1 & 0 & \\
\hline \multicolumn{6}{|c|}{ LOWER SOUTH FORK, HENRY'S FORK, FALL RIVER } \\
\hline Menan Buttes & $18-1 S-20$ & Active, Successful & 1 & 0 & New altemate. \\
\hline Ririe Reservoir & $18-I S-26$ & Unknown & & & \\
\hline Annis Slough & $18-1 S-27$ & Active, Successful & 2 & 0 & $\begin{array}{l}\text { New altemate (old } \\
\text { nest blew down). }\end{array}$ \\
\hline
\end{tabular}


Table 3. Activity and productivity status for bald eagle breeding territories within the Idaho portion of the Greater Yellowstone Ecosystem, 1997 (cont.).

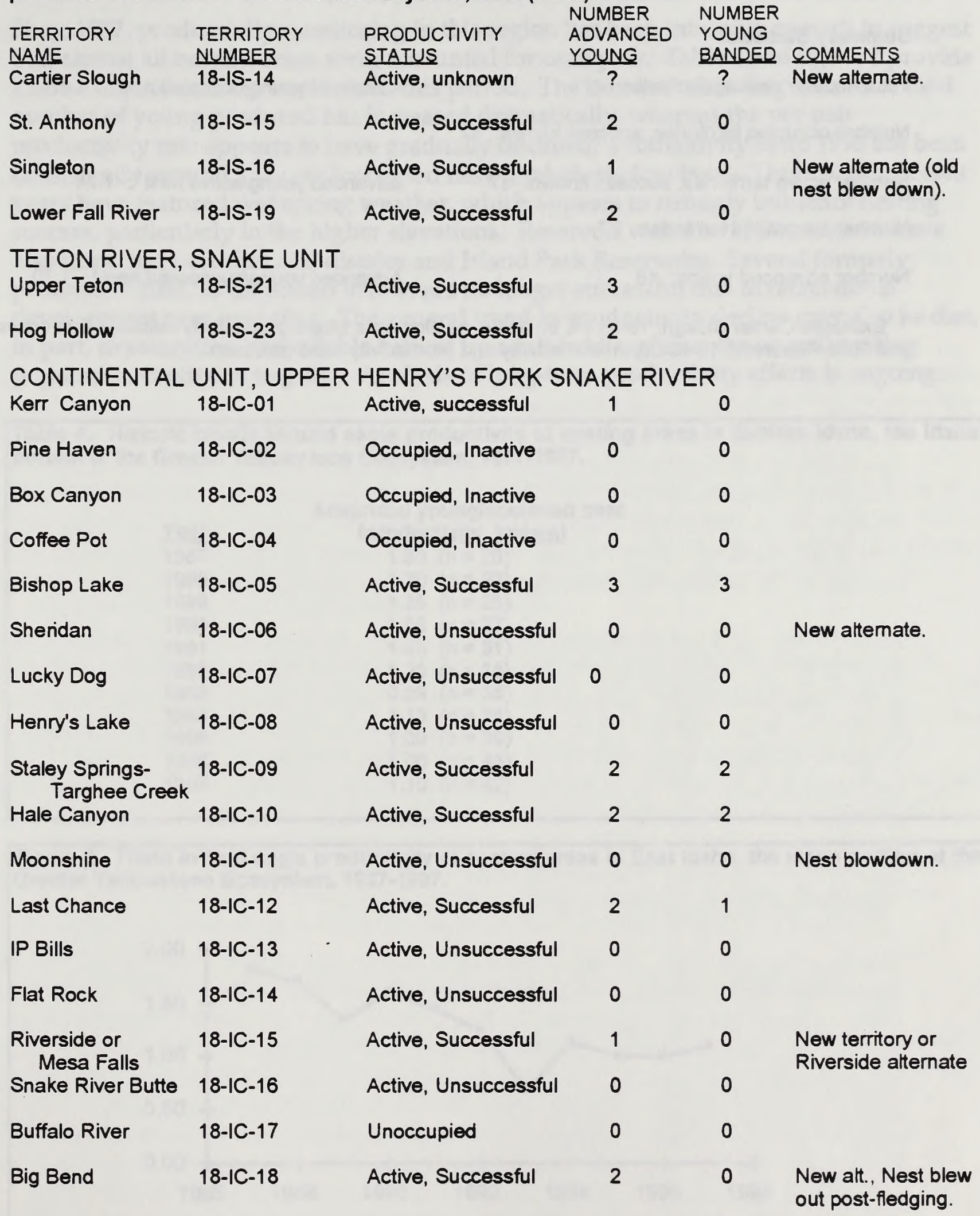


Table 3. Activity and productivity status for bald eagle breeding territories within the Idaho portion of the Greater Yellowstone Ecosystem, 1997 (cont.).

\section{Summary Statistics:}

Total number nesting territories: 47

Advanced young/occupied nest ${ }^{1}: 1.10$

Number occupied territories, success known: 42

Number active territories, success known: 37

Advanced young/active nest ${ }^{1}: 1.24$

Number successful territories: 27

Number advanced young: 46

Advanced young/successful nest ${ }^{1}: 1.70$

1 Excludes Cartier Slough, 18-IS-14, an active nesting area where productivity outcome was unknown, and Ririe Reservoir, 18-1S-26, where activity and productivity were unknown. 


\section{Trends in Bald Eagle Productivity.}

Since 1987, productivity monitoring in this region has been intensive enough to suggest that almost all nesting areas were accounted for each year. Table 4 and figure 2 provide a sense of productivity trends over this period. The number of nesting areas and total number of young produced has increased dramatically, whereas the per pair productivity rate appears to have gradually declined. Productivity since 1993 has been consistently around 1 young/occupied nest, a relatively low level. Three of four recent years have featured wet spring weather, which appears to strongly influence nesting success, particularly in the higher elevations. Reservoir water level fluctuations have also impacted nest sites at Palisades and Island Park Reservoirs. Several formerly productive sites, as discussed below, are no longer successful due to recreational development near nest sites. The general trend in productivity decline may also be due, in part, to saturation of available habitat by adult bald eagles as the overall nesting population continues to grow. Analysis of long-term productivity effects is ongoing.

Table 4. Historic trends in bald eagle productivity at nesting areas in Eastren Idaho, the Idaho portion of the Greater Yellowstone Ecosystem, 1987-1997.

$\frac{\text { Year }}{1987}$
1988
1989
1990
1991
1992
1993
1994
1995
1996
1997

Advanced young/occupied nest (oroductivity known)

$1.80(n=20)$

$1.70(n=23)$

$1.35(n=26)$

$1.59(n=27)$

$1.45(n=31)$

$1.23(n=35)$

$0.69(n=35)$

$1.13(n=38)$

$1.00(n=39)$

$1.00(n=43)$

$1.10(n=42)$

Figure 2. Trend in bald eagle productivity at nesting areas in East Idaho, the Idaho portion of the Greater Yellowstone Ecosystem, 1987-1997.

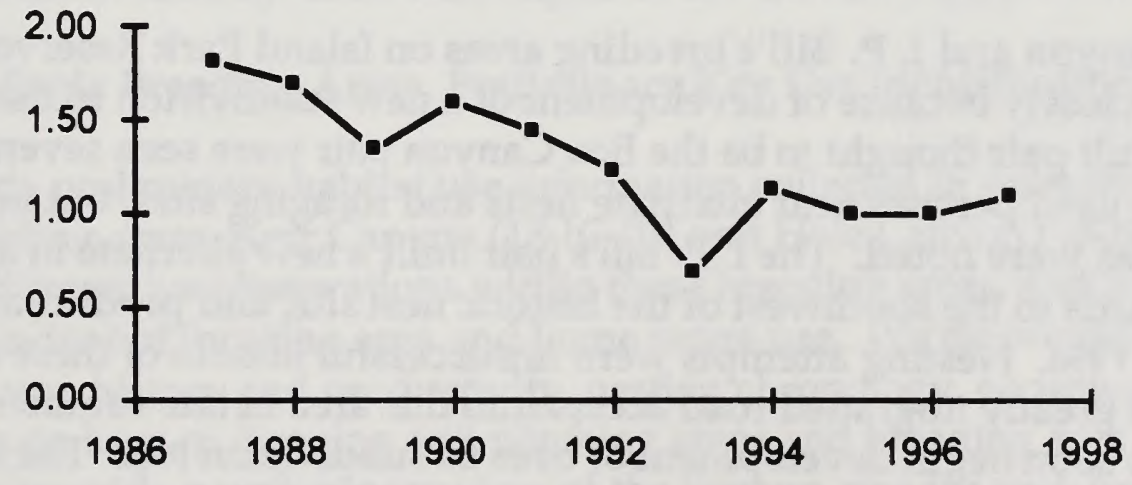




\section{Problem Areas}

As indicated in our report of 1995 observations (Whitfield and Maj 1996), several bald eagle breeding areas with long, productive nesting histories have been nonproductive in recent years. Below, we provide a 1996-97 update for these identified breeding areas.

Henry's Lake, the oldest known bald eagle breeding area in Eastern Idaho, fledged 29 young bald eagles between 1976 and 1992. However, in 1993-96, we have not observed nesting attempts in the known breeding area. No adults were seen in the historic nesting area in 1996. M. Maj found no bald eagles in the vicinity of the historic nest sites on $5 / 22 / 96$. Beginning at dawn, A. Whitfield spent 8.5 hours in the nest vicinity on $7 / 7$, with the hope of detecting an adult moving through the area. He watched from the high ridge top to the north of the historic nest, and also walked through the nest area, but saw no bald eagles. In 1997, the pair incubated on alternate nest $\# 2$, but apparently failed early in the nesting season. Growth in a summer home subdivision near the known nests, with ongoing summer home construction, and a great increase in yearround human use of the primary nest area, may be the cause of this lack of productivity. During early spring surveys in recent years, we have noted evidence of a high volume of snowmachine and four-wheeler traffic in the nest stand. In 1994-1997, the bald eagle study team has searched other Douglas fir stands throughout the home range for potential new alternate nests, but none were located. In 1997, the team noted well defined human trails that pass directly below the known alternate nests.

Before 1992, the Pine Haven breeding area on the Henry's Fork was notably productive. In 1992-97, no active nesting has been detected within this breeding area. Following a pattern noted in recent years, single adult bald eagles were seen perched near the known nests in 1996 and 1997. In recent years, a new river-side lodge, increased summer home development in this stretch of the river, increased river traffic, and recreational activities on the river bank opposite the nests likely contribute to the pair's abandonment of the known nest sites. The bald eagle team and Targhee National Forest volunteers have searched for new nest areas without success. We have also not detected young of the year at traditional foraging areas in later summer when we might suspect that fledged young would be in these areas.

The Box Canyon and I. P. Bill's breeding areas on Island Park Reservoir should be monitored closely because of development of a new subdivision in their vicinity. In 1996, an adult pair thought to be the Box Canyon pair were seen several times on historically used perches near alternate nests and foraging sites, but no active nest nor young eagles were noted. The I. P. Bill's pair built a new alternate in a large Douglas fir about 75 yards to the southwest of the historic nest site, and produced one advanced nestling in 1996. Nesting attempts were unsuccessful in both of these areas in 1997. Developers greatly upgraded road access into this area in late summer 1996, and are expected to soon begin development of over 80 subdivision lots. The area to be developed includes the favored foraging areas used by the Box Canyon pair. The I. P. Bill's pair forages primarily in areas farther to the west, but the nest site is within 
approximately 500 meters of the development, and will likely be affected by increased human activity.

A nest was first built within the Swan Valley breeding area in 1967, the oldest reestablished breeding area on the South Fork. In 4 of 5 years from 1989 to 1993, no young were produced at the historic nest. This pair moved downriver to a less disturbed area in 1994, and produced young in 1995 and 1996. However, in midsummer 1996, a new house and gravel pit were developed near this alternate within a recently platted subdivision. No nesting attempt was observed in 1997, although adult balds were in the breeding area. Development of subdivisions near all of the historic nests in this breeding area is underway, and it now appears that the Swan Valley pair will be forced to nest on the west side of the river if they are to produce young.

From 1988 to 1995, the Palisades Creek breeding area had the highest mean productivity of any site in Eastern Idaho (18 young produced 1988-1995, annual average of 2.25 fledged young). The vicinity of the Palisades Creek nest was entirely platted for subdivision in late 1995 and early 1996. Human use of the nest area increased dramatically in late 1995 and early 1996 as surveyors and planners prepared subdivision plots. The nest failed early in the 1996 breeding season, the first failure at this site in 9 years of known nesting at this site. In 1997, the pair again incubated, but failed at near hatching. Future construction within these subdivisions will at best force the pair to nest away from the activity on the opposite side of the river, and may eliminate this productive breeding area entirely.

A new subdivision was approved for most of the west side of the river in 1996 in the immediate vicinity of the Conant Valley nest used in most years since the late 1970s (29 young produced since 1982). As at the Palisades Creek breeding area, the vicinity of the Conant Valley nest used since 1988 was frequently visited by surveyors and others during the fall and winter of 1995 . As has occasionally occurred in prior years, this pair nested on the large island on the opposite side of the main channel in 1996 and 1997, where two young were produced each year. Should this subdivision be ultimately developed, this bald eagle pair will be forced to alter its activity distribution. The area planned for subdivision features two known alternate nest sites and very important foraging habitat used by adult bald eagles in the Conant Valley breeding area.

\section{Bald Eagle Breeding Areas, Preliminary Key Use Identification, 1996}

We provide preliminary habitat use information collected in summer 1996 for two bald eagle breeding areas, Kerr Canyon (18-IC-01) and Hale Canyon (18-IC-10). We have not completed intensive observations within these breeding areas, and do not know the complete extent of foraging area and home range use. We do provide a summary of breeding area history and productivity, nesting chronology, occupied nest zones, and comments on known foraging and perching areas and breeding area habitat quality. Our maps provide a preliminary view of the key use area for each breeding area. 


\section{Kerr Canyon 18-IC-01}

Breeding Area History. K. Rice observed two adult bald eagles carrying nest material up Kerr Canyon on 4/14/86. A nest was not located in that year, but in August a fledged juvenile was seen with the adults on Ashton Reservoir. On $7 / 18 / 87$, R. Jones and $K$. Rice located nest number one, with two defensive adults, but the nest had blown out of the tree, and no young were located. In subsequent years, the rebuilt nest number one was notably unstable; much nest material fell to the ground before the young were fledged. In the last few years, this nest structure has stabilized. Known nesting in this breeding area has always been in the same Douglas fir up Kerr Canyon.

The Kerr Canyon breeding area has been a very consistent producer of young in every year since establishment. Over the years 1986-1996, an average of 1.45 advanced young/year were produced in the 11 years when productivity was known (Table 5). Nestlings were banded at Kerr Canyon in 1988 (2), 1989 (1), 1991 (1), 1992 (2), 1993 (2), 1995 (2), and 1996 (1). No young banded at this site have been subsequently recovered. The adult female from the Kerr Canyon nest was noted as wearing a USFWS silver band on her left tarsus in 1991, on 6/7/92 and 6/16/96.

On $8 / 2 / 93$, an adult female banded Green with a White stripe (Snake Wyoming) was seen perched on the northwest edge of the Bay where Kerr, Box, and Rattlesnake Canyons enter the reservoir. This was the third adult seen on this date in the Kerr Canyon area, evidence that there may be another nest in the area. Local rancher $C$. Atchley remembers a nest site up Rattlesnake Canyon, to the west of Kerr Canyon, but did not find that nest during a survey in 1997. K. Rice has also seen extra adults on Ashton Reservoir during the nesting season.

\begin{tabular}{|c|c|c|c|c|}
\hline YEAR & NESTING STATUS & $\begin{array}{l}\text { NUMBER } \\
\text { YOUNG } \\
\text { ELEDGED }\end{array}$ & $\begin{array}{l}\text { NEST } \\
\text { NUMBER }\end{array}$ & COMMENT \\
\hline $\begin{array}{l}1986 \\
1987 \\
1988 \\
1989 \\
1990 \\
1991 \\
1992 \\
1993 \\
1994 \\
1995 \\
1996 \\
1997\end{array}$ & $\begin{array}{l}\text { Active, successful } \\
\text { Active, unknown } \\
\text { Active, successful } \\
\text { Active, successful } \\
\text { Active, successful } \\
\text { Active, successful } \\
\text { Active, successful } \\
\text { Active, successful } \\
\text { Active, successful } \\
\text { Active, successful } \\
\text { Active, successful } \\
\text { Active, successful }\end{array}$ & $\begin{array}{l}1 \\
? \\
2 \\
1 \\
1 \\
1 \\
2 \\
2 \\
2 \\
2 \\
1 \\
1\end{array}$ & $\begin{array}{l}1 \\
1 \\
1 \\
1 \\
1 \\
1 \\
1 \\
1 \\
1 \\
1 \\
1 \\
1\end{array}$ & $\begin{array}{l}\text { Adults, } 1 \text { juvenile. Nest not located. } \\
\text { Nest located } 7 / 18 \text {, nest blown out. } \\
\text { Banded } 06 / 11 \text {, est. age } 49 \text { days. } \\
\text { Banded } 06 / 16 \text {, est. age } 56 \text { days. } \\
\text { Nest blowdown. Young fledged. } \\
\text { Banded } 05 / 24 \text {, est. age } 41 \text { days. } \\
\text { Banded } 06 / 07 \text {, est. age } 63 \text { days } \\
\text { Banded female (Snake Wyo.) w Kerr. } \\
\text { Not banded, est. age } 70 \text { days on } 06 / 25 \text {. } \\
\text { Banded } 06 / 01 \text {, est. age } 42 \text { days } \\
\text { Banded } 06 / 16 \text {, est. age } 60 \text { days } \\
\text { Nestling branched out on } 7 / 4 / 97 \text {. }\end{array}$ \\
\hline
\end{tabular}

Nesting Chronology. An estimated date of egg laying is derived from the estimated age of young at banding, or from observation of very young nestlings within two weeks post hatching. The average estimated date incubation was initiated was March 13, with 
a range of March 9 to March 19. The estimated average hatching date is April 23. Nestlings are branched outside the nest in early July, and fledge by mid-July.

Occupied Nesting Zone, Zone 1. There is only one known alternate nest in this breeding area. This nest is approximately 52 feet up in an 85 foot tall Douglas fir. The nest tree base is $1 / 3$ of the way downslope on a $65 \%$ slope with a northwest exposure. The nest tree is the largest tree in a small stringer of trees surrounded by mountain brush and sage. The canyon rim is only about 60 feet from the nest tree, and provides a clear view into the nest.

This nest is located an estimated $1 \mathrm{~km}$ from the reservoir. Although the adults encounter a great deal of human activity in the known foraging areas on Ashton Reservoir, the nest area itself is rarely visited by humans. The adults are vocally intolerant of humans within $600 \mathrm{~m}$ of their remote nest site, particularly if the approach is up the rim of Kerr Canyon.

Key Use Areas, Known Foraging and Perching Areas. The Ashton Reservoir Bay formed at the juncture of Kerr, Box and Rattlesnake Canyons is a favored perching and foraging area for this bald eagle nesting pair and their fledged young. Prey capture attempts have been observed in this bay, along the northwest shoreline of the main reservoir on both sides of the mouth of this bay, and up Willow Creek. The Kerr Canyon pair likely forages over a broader area of the reservoir, and over the wetland areas found to the south of the reservoir. Winter ranges in the vicinity of the nest area also provide ungulate carrion on occasion, particularly in late fall and early spring.

Breeding Area Habitat Quality. Ashton Reservoir is a relatively narrow water body with high levels of recreational use. This human activity likely impacts foraging opportunity on Ashton Reservoir itself. However, there is good foraging habitat on nearby private land ponds, such as the one found up Willow Creek. There are also mammalian prey sources available within the variety of vegetative habitats featured in this area.

Primary fishing areas on Ashton Reservoir and nearby ponds are not available year around due to winter ice cover. However, the breeding area features a variety of potential prey sources, including big game winter ranges, and abundant waterfowl where there is open water. This pair likely ranges over a much greater area during winter. 


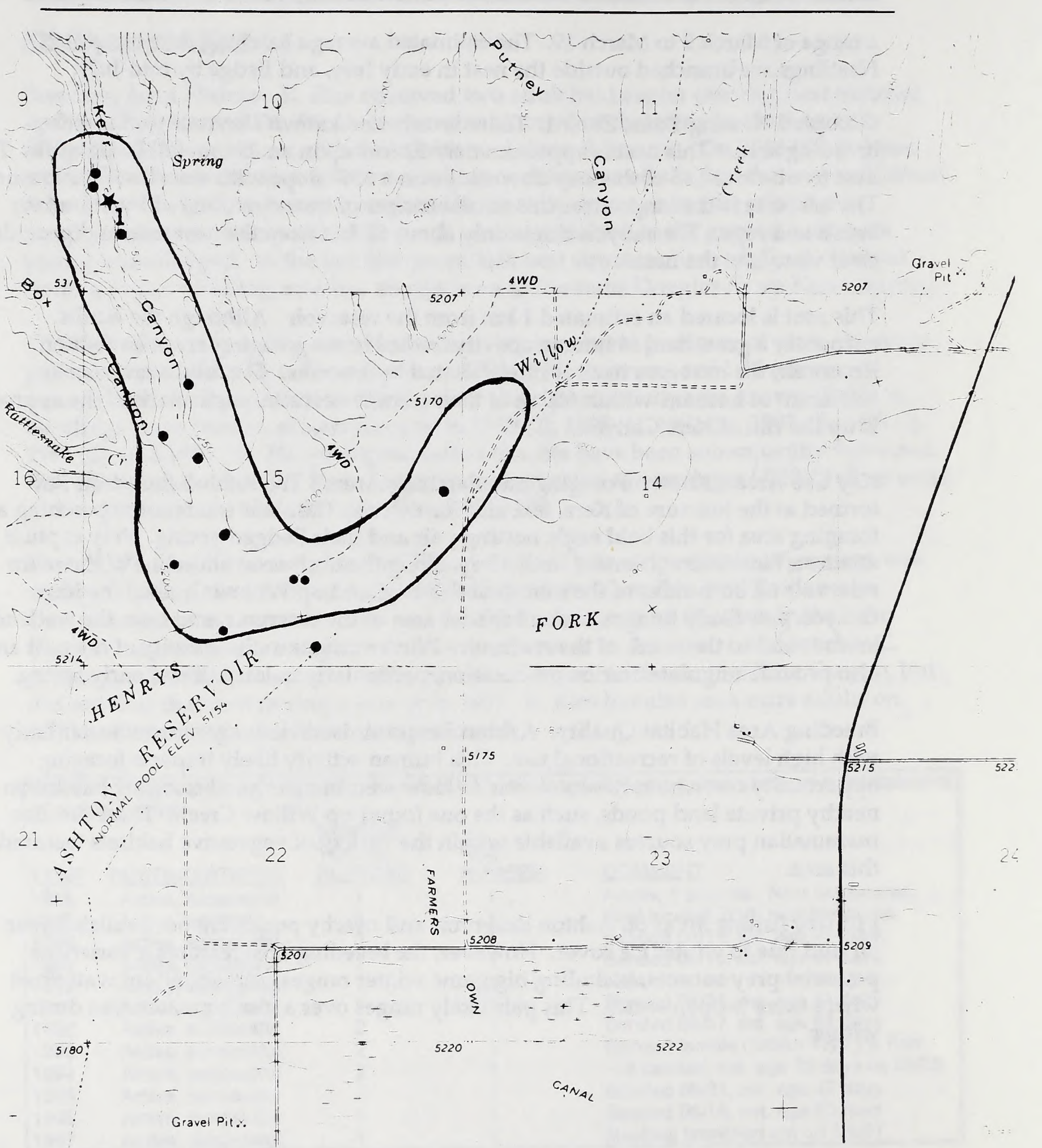

Figure 3. Known key use area within the Kerr Canyon bald eagle breeding area, Ashton Reservoir, Henry's Fork Snake River. Intensive monitoring has not occurred at this breeding area, and the information portrayed is preliminary only. The red line encloses the Principal Management Area. The number indicates the only known nest site. 
Hale Canyon 18-IC-10.

Breeding Area History. As follow-up to fishermen reports received by the Idaho Department of Fish and Game of bald eagle activity in the area, this nest was found in 1989 by the research team. However, Judy and Gordon Smith, nearby residents, reported seeing the nest for approximately three years prior to 1989. The adult female was noted as unbanded in 1996, but there were not clear enough observations of adults in other years at this site to determine band status.

This is a successful bald eagle breeding area. An average of 1.67 advanced young have been produced at this site in the 9 years that productivity has been monitored here (1989-present, Table 6). Interestingly, the site consistently produced 2 young/year for 4 years (1989-1992), then 1 young/ year for 3 years (1993-1995).

Including the 1997 breeding season, all but 2 of 15 young produced at this site since awareness of its existence was learned in 1989 have been banded as advanced nestlings. A nestling banded 05/26/91 at Hale Canyon nest was found electrocuted in Harriman State Park on $10 / 20 / 92$.

Table 6. Known productivity at the Hale Canyon bald eagle breeding area since re-establishment of nesting pairs.

\begin{tabular}{|c|c|c|c|c|}
\hline EAR & NESTING STATUS & $\begin{array}{l}\text { NUMBER } \\
\text { YOUNG } \\
\text { FLEDGED }\end{array}$ & $\begin{array}{l}\text { NEST } \\
\text { NUMBER }\end{array}$ & COMMENTS \\
\hline & Active, unknown & $?$ & 1 & Activity suspected. \\
\hline & Active, successful & 2 & 1 & Banded $06 / 16$, est. age 60 days \\
\hline & Active, successful & 2 & 1 & Not banded, young fledged. \\
\hline & Acitve, successful & 2 & 1 & Banded $05 / 26$, est. age 46 days \\
\hline & Active, successful & 2 & 1 & Banded $05 / 24$, est. age 46 days \\
\hline & Active, successful & 1 & 1 & Banded $06 / 13$, est. age 58 days \\
\hline & Active, successful & 1 & 1 & Banded $06 / 07$, est. age 47 days \\
\hline & Active, successful & 1 & 1 & Banded 06/07, est. age 53 days \\
\hline & Active, successful & 2 & 1 & Banded $06 / 05$, est. age 56 days \\
\hline & Active, successful & 2 & 1 & Banded 05/27, est. age \\
\hline
\end{tabular}

Nesting Chronology. The patterns of incubation in this territory have remained relatively uniform over the past nine years. Dates of observed incubation activities and estimated age of young at banding suggest that incubation is initiated here, on average, March 10, with a range of March 6 to March 17. Hatching occurs around April 14, with fledging in the first two weeks of July. One of the two young apparently fledged early in 1996, as only one fledgling was seen here on $7 / 4$ and $7 / 6$. A fledgling and attendant adult were seen on the nest on 08/06/97 during collection of GPS location data.

Occupied Nesting Zone, Zone 1. Throughout the years, only one nest has been used within this breeding area. This very large nest is 81 feet up in an old-growth live Douglas fir that is approximately 126 feet tall. The nest tree stand is mixed-age Douglas fir near the top of a steep north slope above the river. Above the river rim, the nest 
stand is bordered by cultivated, irrigated fields. To the nesting adults, human activity in these fields is predictable, focused upon agricultural activities, and of little threat. There is little disturbance within the nesting zone because of this nest's relative isolation on a steep slope. A few adventurous fishermen enter the river down a steep path about $.6 \mathrm{~km}$ east of the nest stand and outside of the primary nesting zone.

Key Use Areas, Known Foraging and Perching Areas. The adults were observed foraging and perching near potential foraging areas along the river within $.35 \mathrm{~km}$ of the nest site (figure 4). The adults were seen flying and fishing as far as $5 \mathrm{~km}$ west along the river corridor. Whereas most foraging activity occurs along the river, the adults also soar out over the agricultural fields to the south, and brushlands north the river, with the potential of finding a variety of prey in the diverse habitats found in these areas.

Breeding Area Habitat Quality. Habitat quality in this breeding area is seemingly stable with no development or major alterations in the river corridor or near the nesting area in recent years. There are a number of properties along the river's north side that are on the market, but development of river front properties within this breeding area has not yet occurred.

Both adults, as noted by A. Whitfield during extensive observations in 1996, often left the nest vicinity to fly and fish downriver toward Ashton Reservoir. Fishermen often stopped to fish the river reach below the nest area for extended periods. When fishing activity was heavy near the nest area, with fishermen fishing and anchored directly below the nest and preferred adult perches, the adults remained high on the ridge or left the area completely. 


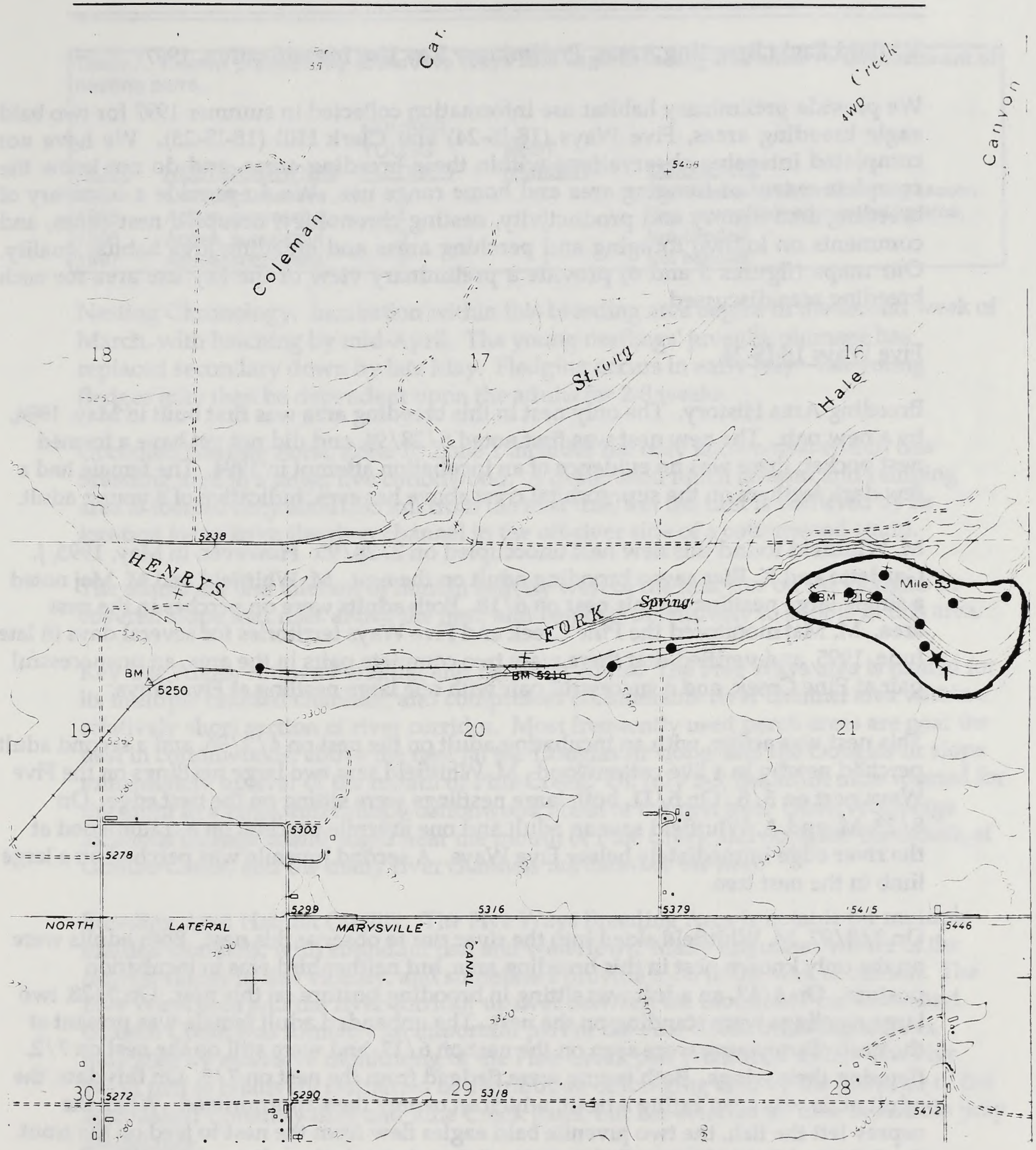

Figure 4. Known key use area within the Hale Canyon bald eagle breeding area, Henry's Fork Snake River. Intensive monitoring has not occurred at this breeding area, and the information portrayed is preliminary only. The red line encloses the Principal Management Area. The number indicates the only known nest site. 


\section{Bald Eagle Breeding Areas, Preliminary Key Use Identification, 1997}

We provide preliminary habitat use information collected in summer 1997 for two bald eagle breeding areas, Five Ways (18-IS-24) and Clark Hill (18-IS-25). We have not completed intensive observations within these breeding areas, and do not know the complete extent of foraging area and home range use. We do provide a summary of breeding area history and productivity, nesting chronology, occupied nest zones, and comments on known foraging and perching areas and breeding area habitat quality. Our maps (figures 5 and 6) provide a preliminary view of the key use area for each breeding area discussed.

\section{Five Ways 18-IS-24.}

Breeding Area History. The only nest in this breeding area was first built in May, 1994, by a new pair. The new nest was first noted $5 / 28 / 94$, and did not yet have a formed nest pocket, there was no evidence of an incubation attempt in 1994. The female had a few dark feathers on the supraorbital crest above her eyes, indicative of a young adult.

M. Whitfield found this new nest unoccupied on 2/28/95. However, in May, 1995, J. Gardetto and K. Rice saw a brooding adult on the nest. $M$. Whitfield and M. Maj noted a single large nestling on this nest on $6 / 18$. Both adults were on perches in the nest area. M. Maj monitored the Pine Creek and Five Ways territories for several days in late June, 1995, and verified that there were two complete pairs in the area, an unsuccessful pair at Pine Creek, and a successful pair with one large nestling at Five Ways.

This nest was active, with an incubating adult on the nest on $4 / 3 / 96$, and a second adult perched nearby in a live cottonwood. M. Whitfield saw two large nestlings on the Five Ways nest on $5 / 8$. On $6 / 11$, both large nestlings were sitting on the nest edge. On $8 / 23, \mathrm{M}$. and A. Whitfield saw an adult and one juvenile perched on a cottonwood at the river edge immediately below Five Ways. A second juvenile was perched on a large limb in the nest tree.

On 3/9/97, M. Whitfield skied into the river rim to observe this nest. Both adults were on the only known nest in this breeding area, but neither bird was in incubation posture. On $4 / 17$, an adult was sitting in brooding posture on this nest. On $5 / 28$, two large nestlings were standing on the nest. The unbanded adult female was present at the nest. Two young were seen on the nest on $6 / 17$, and were still on the nest on $7 / 2$, flapping their wings. Both young were fledged from the nest on $7 / 3$. On this date, the adult male was seen eating a trout, which an osprey then appropriated. When the osprey left the fish, the two juvenile bald eagles flew from the nest to feed on the trout. On $7 / 10$ and $7 / 15$, the two fledges were flying about the breeding area and food begging. Neither fledge was seen during a brief observation on $8 / 18$. 


\begin{tabular}{|c|c|c|c|c|}
\hline YEAR & NESTING STATUS & $\begin{array}{l}\text { NUMBER } \\
\text { YOUNG } \\
\text { ELEDGED }\end{array}$ & $\begin{array}{l}\text { NEST } \\
\text { NUMBER }\end{array}$ & COMMENTS \\
\hline $\begin{array}{l}1994 \\
1995 \\
1996 \\
1997 \\
\end{array}$ & $\begin{array}{l}\text { Occupied, inactive } \\
\text { Active, successful } \\
\text { Active, successful } \\
\text { Active, successful }\end{array}$ & $\begin{array}{l}0 \\
1 \\
2 \\
2\end{array}$ & $\begin{array}{l}1 \\
1 \\
1 \\
1\end{array}$ & $\begin{array}{l}\text { New nest built late in breeding season. } \\
\text { First young fledged in breeding area. } \\
\text { Not banded. } \\
\text { Not banded. }\end{array}$ \\
\hline
\end{tabular}

Nesting Chronology. Incubation within this breeding area begins in the second week of March, with hatching by mid-April. The young nestlings' juvenile plumage has replaced secondary down by late May. Fledging occurs in early July. The young fledges may then be dependent upon the adults for 2-8 weeks.

Occupied Nesting Zone, Zone 1. Zone 1 includes the only known nest within this breeding area in a large, live cottonwood. A designated lunch takeout and camping area is located only about $.35 \mathrm{~km}$ from the nest tree, but the nest is sheltered by its location away from the river channel in the off-river side of a cottonwood stand.

The adults are less tolerant of human activity west of the nest tree on the Douglas fir covered slope that rises above the nest, and respond defensively to people in this area.

Key Use Areas, Known Foraging and Perching Areas. The Five Ways area is named for its multiple braided channels, and compresses considerable river channel area within a relatively short section of river corridor. Most frequently used perch areas are near the nest in cottonwoods, above the nest on the Douglas fir slope, and the Douglas fir slope immediately upriver of the mouth of Pine Creek. On July 2-3, the adult male roosted for the night in a large, full canopy cottonwood north of the nest tree. Observed forage locations include island edges near the mouth of Pine Creek and opposite the mouth of Granite Creek, and the many river channels northeast of the nest.

Breeding Area Habitat Quality. The Five Ways Breeding Area is notable for multiple braided channels, with abundant fish and waterfowl. Many ungulates winter of the canyon slopes in this vicinity, and sometimes provide food in the way of carrion. The Five Ways area and the river corridor upriver between the mouth of Pine Creek and Granite Creek was formerly an important part of the Pine Creek breeding area, as indicated by extensive monitoring of the Pine Creek pair (Whitfield 1993). The Five Ways pair is relatively restrained in distribution of foraging area by the presence of the established Conant Valley and Pine Creek pairs, but has selected an area of notable prey abundance.

The nest is within 400 meters of a designated lunch/camping area. The pair is tolerant of people in this area. Use by people of the area toward the nest from the takeout should be discouraged. 


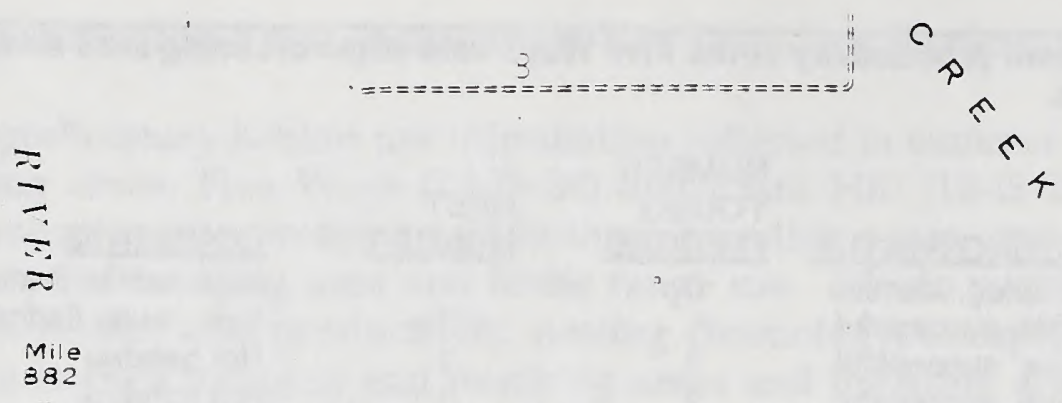

(Pine $\underset{\star}{\text { Cr. Nest) }}$
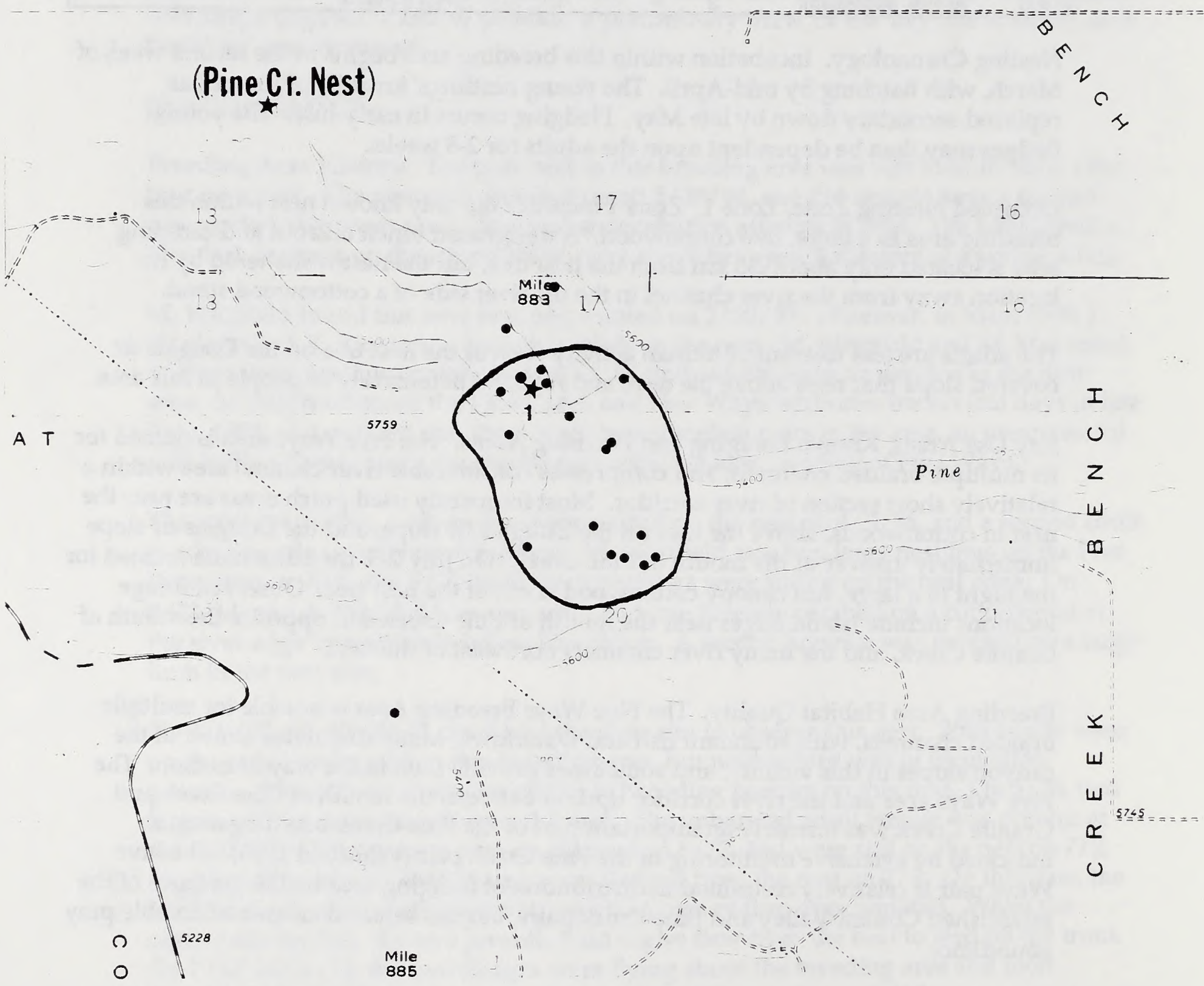

Figure 5. Known key use area within the Five Ways bald eagle breeding area, South Fork Snake River. Intensive monitoring has not occurred at this breeding area, and the information portrayed is preliminary only. The red line encloses the Principal Management Area. The number indicates the only known nest site. 


\section{Clark's Hill 18-IS-25}

Breeding Area History. K. Rice reported a new nest in cottonwoods below Clark's Hill in mid-March, 1996. Neither adult at this site was banded. Two young successfully fledged in 1996. M. Maj saw an unbanded adult perched in the cottonwood stand upriver of the nest, and another incubating on the nest on $3 / 21 / 96$. On $4 / 3, M$. Whitfield, K. Rice, and W. Brown observed the nest (and incubating adult) and plotted its location. M. Whitfield and M. Maj saw a brooding adult low on this nest on 5/9. A. Whitfield saw two large young on the nest edge on $6 / 13$. The larger of the two nestlings frequently wing-flapped. A. Whitfield saw a fledged youngster and unbanded adult male in this nesting area on $8 / 23$.

On $3 / 9 / 97$, the nest was newly built up, but there were no bald eagles within the nest vicinity. A pair of adults was seen perched together about 1 mile downriver. On 3/27, $M$. Whitfield saw an incubating adult on this nest. An adult was seen in brooding posture on this nest on $4 / 15$. On $6 / 7, \mathrm{~S}$. Austin monitored this site for five hours. Two large, vigorous young were on the nest. On 6/9, M. Whitfield and J. Gardetto visited the nest for banding, and found that part of the nest and one nestling had fallen out of the tree. The dead nestling was partially consumed. During this observation, the adult female (unbanded) delivered a fish to the youngster on the nest. This juvenile had successfully fledged by $7 / 7$, and was seen in the breeding area begging for food during observations on $7 / 17,7 / 18$, and $8 / 13$.

Table 8. Known productivity at the Clark Hill bald eagle breeding area since re-establishment of nesting pairs.

\begin{tabular}{|c|c|c|c|c|}
\hline YEAR & NESTING STATUS & $\begin{array}{l}\text { NUMBER } \\
\text { YOUNG } \\
\text { ELEDGED }\end{array}$ & $\begin{array}{l}\text { NEST } \\
\text { NUMBER }\end{array}$ & COMMENTS \\
\hline $\begin{array}{l}1996 \\
1997\end{array}$ & $\begin{array}{l}\text { Active, successful } \\
\text { Active, successful }\end{array}$ & $\begin{array}{l}2 \\
1\end{array}$ & 1 & $\begin{array}{l}\text { New nest, cottonwood, not banded. } \\
1 \text { advanced nestling died pre-fledging. }\end{array}$ \\
\hline
\end{tabular}

Nesting Chronology. An estimated date of egg laying is derived from observations of adult behavior, from observation of very young nestlings within two weeks post hatching, or from the estimated age at banding. At this site, our chronology estimates are based on less information than at most sites; this is a new breeding area. The estimated date incubation is initiated, judging from juvenile development, is around March 10-15, with hatching by mid-A pril. By late May the young can survive without brooding. Nestlings are branched outside the nest in late June, and fledge in the first or second week of July. The young fledges may be dependent upon adults for 2-8 weeks.

Occupied Nesting Zone, Zone 1. Zone 1 includes the downriver end of the old growth cottonwood stand near a slough at the edge of Clark's cultivated land below the Clark Hill Overlook (figure ). The nest is located on the off-river side of a very densely vegetated island penninsula, and human disturbance at this site is unlikely. 
Key Use Areas, Known Foraging and Perching Areas. Figure 6 indicates perches, roosts and foraging locations detected during observations made during the 1997 nesting season. Most of the adult perches were in the nest vicinity in cottonwoods near the river, and Douglas fir and cliff points overlooking the river channel. Noted forage locations were in the river channel that flows in front of the nest island, and downstream of river mile 856 in the cottonwood stand on the northeast side of the river.

Breeding Area Habitat Quality. This breeding area features considerable human activity emanating from the South Fork road on the opposite side of the river, the overlook above the canyon rim south of the nest, and from float traffic in the river channel. The area of the nest tree is not generally accessible to human disturbance because of dense vegetation and backwater sloughs. The river corridor in the nest area and downstream features many braided channels, and is expected to provide an abundant prey base. 


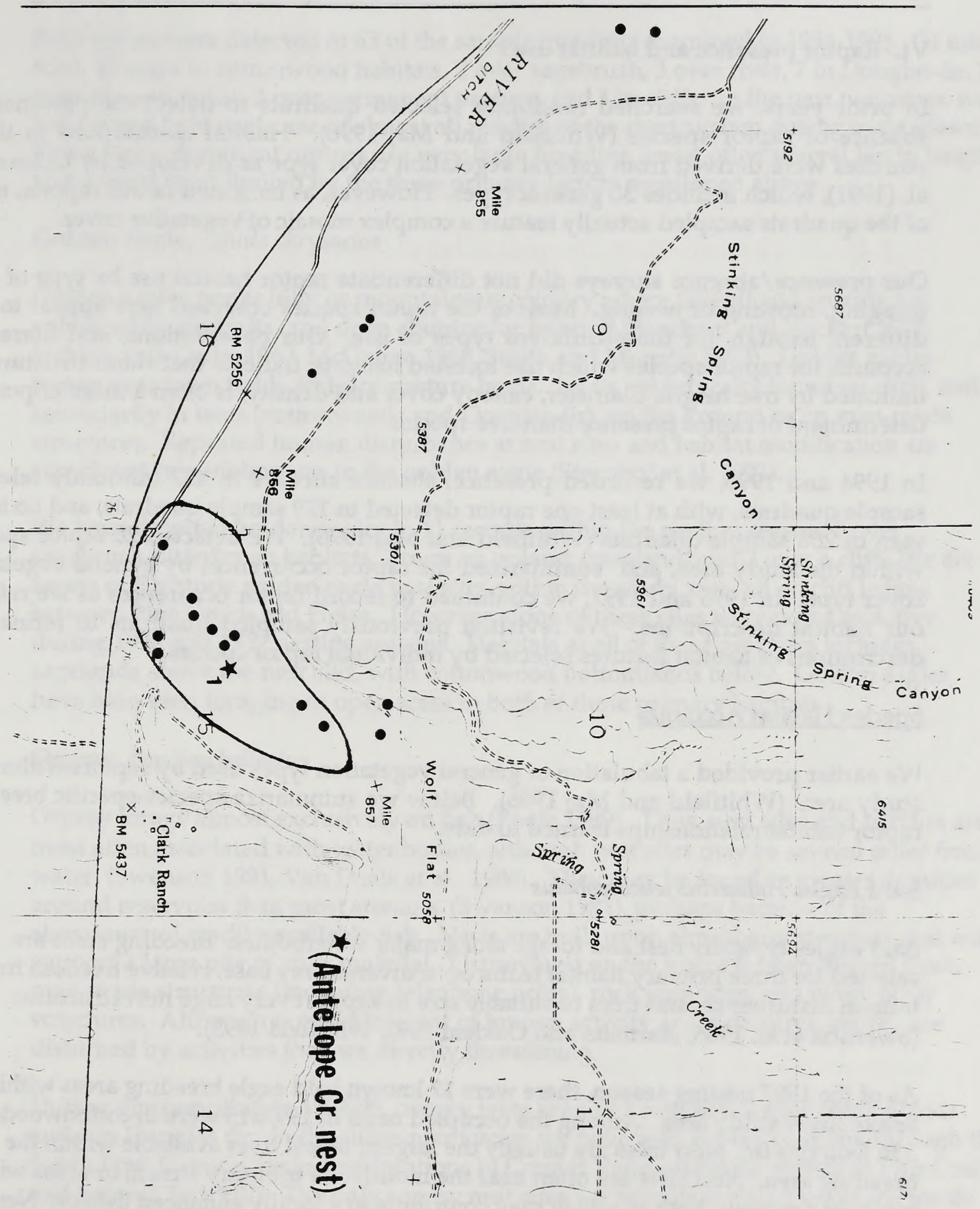

Figure 6. Known key use area within the Clark Hill bald eagle breeding area, South Fork Snake River. Intensive monitoring has not occurred at this breeding area, and the information portrayed is preliminary only. The red line encloses the Principal Management Area. The number indicates the only known nest site. 


\section{Raptor presence and habitat use}

In prior years, we searched randomly selected quadrats to detect the presence or absence of raptor species (Whitfield and Maj 1996). Habitat associations in these searches were derived from general vegetation cover type as developed by Ulliman et al. (1991), which includes 30 general types. However, as indicated in our reports, most of the quadrats sampled actually feature a complex mosaic of vegetative cover.

Our presence/absence surveys did not differentiate raptor habitat use by type of use, foraging, roosting or nesting. Most of the raptor species observed here appear to use different habitats for these different types of use. Our observations, and literature accounts for raptor species which use forested habitats, indicate that stand structure, as indicated by tree height, diameter, canopy cover and density, is often a more important determinant of raptor presence than tree species.

In 1994 and 1995, we recorded presence/absence surveys in 437 randomly selected sample quadrats, with at least one raptor detected in 179 sample quadrats, and no birds seen in 258 sample quadrats (Whitfield and Maj 1996). We detected 20 raptor species within the study area, and summarized the raptor occurrences by general vegetative cover type. In 1996 and 1997, we continued to record raptor occurences as we refined our habitat descriptions. We revisited previously sampled quadrats to refine our descriptions of habitat features selected by individual raptor species.

\section{Species Habitat Accounts}

We earlier provided a tabulation of general vegetation types used by raptors within our study area (Whitfield and Maj 1996). Below we summarize species-specific breeding raptor habitat relationships learned to date.

\section{Bald Eagle, Haliaeetus leucocephalus}

Bald eagles typically nest and forage along major waterbodies. Breeding areas are selected for three primary habitat features: a diverse prey base, relative freedom from human disturbance, and trees of suitable size to support very large nest structures (Swenson et al. 1986, Harmata and Oakleaf 1992, Whitfield 1993).

As of the 1997 nesting season, there were 17 known bald eagle breeding areas within the Snake River study area. Among the occupied nests in 1997, 15 were in cottonwoods and 2 in Douglas fir. Nest trees are usually the largest, tallest trees available within the breeding area. Nest sites are often near the mouth of a tributary stream or areas with multiple channels, both of which may contribute to a locally enhanced fishery. Nests are usually located on shorelines or islands where human activity is deterred by vegetation or topography. 
Bald eagles were detected in 63 of the sample quadrats examined in 1994-1995. Of this total, 46 were in cottonwood habitats, 2 over sagebrush, 3 over river, 7 in Douglas-fir, 2 over plowed fields, 2 over permanent pasture, and 1 in cliffs. In the past two years, we have noted bald eagle use of almost all reaches of the river system during some season. These large, dominant raptors use very large breeding areas, often several $\mathrm{km}$ in length, and appear most limited by the three primary factors mentioned above.

\section{Golden Eagle, Aquila chrysaetos}

Golden eagles prefer hilly or mountainous country where takeoff and soaring are enhanced by updrafts, and open country for hunting (Beecham and Kochert 1975, Hobbie and Cade 1962, McGahan 1968, Smith and Murphy 1973). Golden eagles forage over open fields and dry pasture lands. Nests are typically found on cliffs, and secondarily in trees (cottonwoods and Douglas-fir), on the ground or on man-made structures. Repeated human disturbance at nest sites and habitat modification are significant current impacts to the golden eagle (Steenhof et al. 1991).

We have detected golden eagles in 11 records within the nesting season, 7 over sagebrush-bitterbrush habitats, 2 over an upland grassland, and 2 over a cliff. We are aware of 5 historic golden eagle nest sites within the study area, all on cliff ledges between Pine Creek and Heise. However, none of these sites were noted as active during 1996 and 1997 nesting seasons. Habitats at all of these nest sites includes sagelands above the nest cliff, with cottonwood bottomlands below. Golden eagles have been seen foraging in open areas in both of these primary habitats.

\section{Osprey, Pandion haliaetus}

Osprey forage almost exclusively on fish (Poole 1989). Thus, nest sites and perches are most often associated with water bodies, although nest sites may be several miles from water (Swenson 1981, Van Daele et al. 1980). They may be found in greater densities around reservoirs than most streams (Swenson 1981), perhaps because of the abundance of readily available fish. Nests are built upon almost any structure that will support a large pile of stick material. Osprey nest on the top of broken topped trees, man-made structures (including telephone poles), rock pinnacles, and many other structures. Although notably tolerant of human activity and structures, osprey are disturbed by activities that are directly threatening.

During our sampling in 1994-95, osprey were seen in 3 samples, 2 over cottonwoods and 1 in Douglas fir. In the subsequent years we have seen osprey coursing through the South Fork Canyon, including locations in Conant Valley, near the mouth of Pine Creek, and below Clark Hill. The only osprey nest sites we have discovered are at the trestle below Heise, along the lower river below the confluence and on the lower Henry's Fork. We suspect a nest in the Conant Valley area some distance from the river. Most known nests are on man-made structures, and do not appear to be associated with any specific 
vegetative features. Prey availability appears to be the primary determinant of osprey occurence.

\section{Northern Goshawk, Accipiter gentilis}

The northern goshawk is most often associated with mature and old growth forests, relatively open forests with flight alleys below the canopies (Reynolds et al. 1982). Most nest sites found on the nearby Targhee National Forest are in mature Douglas fir, with some sites in aspen and lodgepole (Patla 1991). This species is intolerant of human disturbance, and requires nesting areas that are relatively free of human activity. Goshawks forage in many habitats for a variety of birds and mammals, including open pastures, sagelands, and a variety of forested habitats.

We have seen goshawks on six occasions within the Snake River study area, three observations in Douglas fir, two in aspen forests, and one in a cottonwood stand. One goshawk nest site is known in a large, mature cottonwood stand on the lower South Fork Another is located in a mature, open-grown Douglas fir stand on a north exposed South Fork tributary. Both of these stands are adjacent to undeveloped open habitats, wet meadows in the case of the cottonwood nest, sagelands near the Douglas fir stand. Within mature aspen stands in the Rocky Canyon area above the river canyon rim, we found five old goshawk nests. Among these aspen nest trees, average tree height was 58 feet, nest height 40 feet, and DBH 12.9 inches. All five aspen nests were in areas with dense shrub understory 3 to 6 feet tall. Expansive shrublands surround these aspen stands. We have seen adult goshawks in this general area predating upon waterfowl in early spring.

\section{Cooper's Hawk, Accipiter cooperii}

The Cooper's hawk nests within deciduous and mixed forests such as those found along riparian zones, and within small woodlots or in semiarid stands (Reynolds 1989). More so than other accipiters, Cooper's hawks will utilize open, small forested stands and second growth forests (Beebe 1974, Reynolds et al. 1982, Moore and Henny 1983). When found in large continuous forests, Cooper's hawks often nest near the edge of the stand. Cooper's tend to build nests within the tree crown canopy or on mistletoe growths. Both strategies are thought to provide more cover and security from predators (Moore and Henny 1983). Cooper's hawks tend to nest in conifer stands intermediate in age and tree density to areas selected by sharp-shinned hawks and goshawks, with sharp-shinned hawks in the younger, denser stands (Reynolds 1983).

We have thus far recorded five occurrences of Cooper's hawk, 3 in cottonwood forests, and 2 in Douglas fir. Two Cooper's hawk nest sites were recorded in cottonwoods within the study area. The nest sites were in relatively large, mature cottonwood stands with canopy closure averaging $70 \%$ and moderate shrub understory. The Douglas fir forests where nests were located were of mixed age, with interspersed aspen. Canopy coverage around the nests was $100 \%$, but varied greatly in the near vicinity. 
Sharp-shinned Hawk, Accipiter striatus

Sharp-shinned hawks use the youngest, most dense forests stands of the three accipiter species. Cover from predatory raptors is important to this small accipiter. Sharpshinned hawks nest in the thick foliage of dense conifer stands and some mixed deciduous forests (Reynolds et al. 1982, Moore and Henny 1983, Reynolds 1989). The combination of a conifer patch within a larger deciduous stand is thought to provide preferred nesting habitat ( Platt 1976, Reynolds 1989, Joy et al. 1994). Sharp-shinned hawks may prefer north facing conifer stands thought to represent more mesic habitat (Reynolds and Wight 1978). Foraging occurs in a variety of habitats, including shrub communities, deciduous and conifer forests and open habitats adjacent to nesting habitat. Conifer stands are identified as important in providing a diversity of passerine bird species, the primary prey of this highly specialized, bird-catching predator (Joy et al. 1994).

All five of our sharp-shinned hawk observations within the Snake River study area were in Douglas fir habitats above the river bottom. The Douglas fir stands were mature but stagnant with relatively small diameter, densely-grown trees. Slopes were relatively steep, about $40 \%$, and north exposed. Canopy closure averaged $75 \%$. Shrub understory was dense, with lots of ninebark in several locations.

\section{Red-tailed Hawk, Buteo jamaicensis}

Red-tailed hawks are diverse in nest site selection; conifers and hardwoods or on cliffs or other elevated sites where trees are lacking (Smith and Murphy 1973, Johnson 1975). In forested areas, nests are typically in the crowns of tall trees or in trees on high points (Titus and Mosher 1981). Nests are usually at the edge of dense stands or within open canopy forests in tall trees, not in the interior of dense forest (Gates 1972), although they will occasionally nest in large tracts of unbroken forest. Red-tailed are associated with grasslands that feature more tall trees (perch sites) than are sympatric Swainson's and rough-legged hawks (Cottrell 1981, Janes 1985). In forested settings, red-tailed hawks nest and perch in forest edges near open areas. Red-tailed hawks are often found in upland hardwood forests, aspen and cottonwoods in the northern Rockies, and grass dominated cover types. Most of the hunting is in short grass areas (Peterson 1979). Howell et al. (1978) noted that breeding areas with high proportions of fallow pasture relative to crop pasture had greater productivity. Roosting is most commonly in groups of trees with dense foliage.

Red-tailed hawks occurred in 44 of our sample quadrats, with 21 in cottonwood stands, 8 over sagebrush, 7 in Douglas fir forest, 3 in aspen, 1 over small lodgepole, and 2 over plowed fields. We detected nesting by red-tailed hawks in 7 cottonwoods, 1 aspen and 2 Douglas fir habitats. All of the cottonwood nests were in tall, prominent cottonwoods in lower river areas, with dense shrub understory in the nest stands, and open areas nearby. The aspen nest was in a small, stunted aspen stand in the middle of cultivated 
fields. The Douglas fir nest was in a prominent old-growth tree at the edge of a large stand of mature and old-growth trees.

Swainson's Hawk, Buteo swainsoni

Swainson's hawk nesting areas are usually in broken grasslands and cultivated areas with scattered trees (Dunkle 1977). These hawks return to old nests, and also use old magpie nests, or old crow or raven nests (Fitzner 1978). Swainson's hawks commonly forage over hayfields and meadows. Woodbridge (1987) reported that Swainson's hawks in California strongly preferred irrigated alfalfa fields over drier rangelands, probably because of the greater prey base. Bechard (1982) found that cultivated fields were not highly used for foraging until after crop harvest had reduced plant cover. He suggested that vegetative cover may have been more important in foraging habitat selection than relative prey density.

Swainson's hawks were seen 21 times: 8 in cottonwood habitats, 6 over croplands, 3 over grazed grasslands, 2 over plowed fields, and 2 perched at the edge of a Douglas fir forest. We saw this species near residential areas and cultivated fields. Swainson's hawk nests were found in cottonwood (2), aspen (1), and Douglas fir (1). Nests were within the canopies of sub-dominant trees, and, with the exception of one cottonwood nest on the river edge, were difficult to detect.

\section{Feruginous Hawk, Buteo regalis}

Feruginous hawks are typically resident of wide-open grassland habitats (Thurow and White 1983). This species generally avoids forested or cultivated areas.

We did not observe feruginous hawks in the study area, although we have seen feruginous hawks in the region.

\section{Northern Harrier, Circus cyaneus}

The northern harrier nests and forages in marshlands, fields, open shrublands, and dry shrublands. The harrier is specifically associated with mesic grasslands and wetland habitats for nesting. Harriers nest on the ground, where their nests and young are vulnerable to predation. Harriers forage in a diversity of habitats, but use mesic sites and cultivated areas disproportionate to their occurrence. Harriers may also be found in dry shrub steppe habitats, including sage and grassland habitats (Martin 1987). The northern harrier relies on hearing to locate prey to a much greater degree than other diurnal raptors, and thus is able to hunt in habitats with greater ground cover (Johnsgard 1990).

We saw hunting harrier, or marsh hawks on 15 occasions: 7 over sagebrush, 5 over grasslands, 2 over wet meadows, and 1 over willow and other shrubs. We found 3 nesting marsh hawk nests in CRP seeded grasslands on the river rim. We detected this 
species only in open habitats, but in a wide range of habitats from wetlands in the river bottom to dry grasslands above the river rim.

\section{Peregrine Falcon, Falco peregrinus}

Peregrine falcons typically nest on large, dominant cliffs over 150 feet high with prominent views of the surrounding area (Cade 1992). Prey are usually shorebirds, waterfowl, or pigeons, with foraging over a wide variety of habitats (Sherrod 1978).

Peregrine falcons were detected 4 times: 1 flying over and 1 perched in Douglas fir, and 2 in cliffs. One of two known peregrine aeries within the study area fell within a sample quadrat. Both of the known aeries were on cliff ledges, one a very large cliff system overlooking the river bottomlands and adjacent sage and juniper habitats, and the other on a small cliff between a Douglas fir forest and cottonwood bottoms. The great variety of habitats found along the South Fork corridor provides an abundant and diverse prey base for this species.

\section{Prairie Falcon, Falco mexicanus}

Prairie falcons select nesting aeries in cliffs or escarpments. The landscapes surrounding their nests sites are often semi-arid open lands, sagebrush basins or grasslands (Marti and Braun 1975). They also nest at higher elevations on large cliff systems within montane to sub-alpine forest. Nests are usually in rock cavities in sheer cliffs with overhanging ledges and a broad vista. Most nests are within pothole-like cavities in cliffs about $30 \mathrm{~m}$ high (Runde and Anderson 1986). Prairie falcons also nest in rock crevices and old stick nests used by other species.

We twice saw prairie falcons soaring over sagebrush habitats above the river rim near a cliff top. We are aware of three prairie falcon aeries within the study area, all within cliffs overlooking the river bottomlands.

\section{Merlin, Falco columbarius}

Merlins typically nest in mixed grasslands and deciduous woodlands, and sometimes in dry conifer sites (Sieg and Becker 1990). Foraging occurs in mixed sage and grassland.

We have not seen any merlins in our observations during this study, although we have seen merlins in the study area on two earlier occasions. The observed birds were hunting in open shrublands.

\section{American Kestrel, Falco sparverius}

The American kestrel is a secondary cavity nester; it uses nesting cavities which were excavated by other species. As such, the kestrel is dependent on the northern flicker over much of its distribution (Balgooyen 1976). Kestrels often displace woodpeckers, 
and compete with screech owls and other species for suitable cavities (Balgooyen 1976). Highly valued cavity trees are aspen and cottonwood.

Kestrels have a wide ecological tolerance relative to elevation, tree species and type of forested environment. Kestrel distribution is strongly influenced by the availability of adequate nesting cavities and perches (Sedgwick and Knopf 1990). Since over 95\% of forages are initiated from a perch, and prey is usually taken at ground level, perches within open areas are important habitat features (Balgooyen 1976). Hunting usually occurs over open terrain, with a preference for open, exposed ground in vegetated areas.

We frequently saw kestrels in cottonwood habitats (17 observations), and less often in aspen (4), over sagebrush (4), in lodgepole stands (1), in Douglas fir (4), in juniper (1), over a plowed field (1), and in mountain mahogany (1). We detected 7 nesting kestrel pairs in cottonwood riparian forest habitats. Nest sites were in cavities in older-aged trees at the edge of large stands or in small stands in the middle of openings. We did not find kestrel nests in forest interiors.

\section{Turkey Vulture, Cathartes aura}

Turkey vulture nesting habitat includes arid western plains and mountains, temperate forests and tropical lowlands (Pattee and Wilbur 1989). Nests are located on rock ledges in caves, down trees and buildings. (Jackson 1983, Coleman and Fraser 1989). These ledges are not necessarily high or large in area. Nest material is not brought in, but a scrape may be made in the ledge substrate. Turkey vultures appear to usually select nest sites that are within a forested environment and that have few roads and no buildings (Coleman and Fraser 1989). They also tend to perch and soar near their roosts and perch near nest sites.

Turkey vultures were detected in 9 times, 4 over sagebrush, 2 perched in Douglas fir forest, 1 over cliffs, 1 over plowed field, 1 perched in a large cottonwood. These birds were seen soaring over a variety of habitats, often over Douglas fir along the canyon rims. Several of these observations were of groups of vultures soaring together along the canyon rim. However, these flights appeared to be more dependent upon topographic relief than vegetative cover. We did not detect any nest sites.

\section{Great Horned Owl, Bubo virginianus}

The great-horned owl is found in a broad range of habitats (Austing and Holt 1966, Petersen 1979, Johnsgaard 1988, Rohner and Doyle 1992). The great-horned owl is probably the most common nocturnal raptor within our study area. Basic habitat needs are a nest site, roost site, and hunting area. Nests are usually stick nests built by other birds, such as red-tailed hawks or herons; great-horned owls also use cliff nests, ledges, and caves. Roosts are selected for maximum daytime concealment, conifers are favored. 
Hunting areas are usually relatively open areas, but woodlands or areas with scattered trees are also used.

We have noted 21 records of great horned owls within the study area to date, 1 in aspen, 8 in Douglas fir, 2 in cliffs, and 10 in cottonwood forests. Vocalizing and foraging adults and one juvenile were most often found in trees at the edge of openings. Within forest observations were in mature stands with minor shrub understory.

Eight known nest sites have been noted, as follows: 5 in large cottonwoods in a redtailed or Swainson's hawk nest, 1 in a large Douglas fir in a red-tailed hawk nest, and 2 on cliff ledges. Nest sites are typically in prominent trees, sites that may more directly reflect the habitat preferences of the primary nest builders, buteo hawks. The nest vicinities were generally mixed habitats, with dense shrub understory in nest stands, and open areas nearby. Cottonwood canopy cover in nest stands averaged $40 \%$, and the Douglas fir nest was in a forest with almost $100 \%$ closure. This later nest was only $50 \mathrm{~m}$ from the forest edge adjacent to an open field.

\section{Long-eared Owl, Asio otus}

During the breeding season, long-eared owls are associated with coniferous, deciduous, or mixed composition forests (Johnsgard 1988), usually in areas adjacent to open grasslands or shrublands. In western Idaho, long-eared owls are found nesting in cottonwood, willow and juniper habitats (Marks 1986), and use old corvid nests almost exclusively. In eastern Idaho, nest sites have been noted in dense aspen stands, in mixed lodgepole pine/Douglas fir forests, and in juniper woodlands, usually at the edge of large open areas (Craig et al. 1988). In other areas, nesting has been noted in old red-tailed hawk and accipiter nests. Long-eared owls will also nest on platforms formed by mistletoe clumps.

During winter, dense conifer forests may be very important as roosting cover (Craighead and Craighead 1956). Large numbers of these owls will sometimes congregate at favored winter roosts in dense willow thickets within riparian bottoms (Bent 1938, D. Holt pers. comm.). Roosts may be used repeatedly over the years.

Within the Snake River study area, long-eared owls have now been noted in 6 records, 4 in Douglas fir and 2 in riparian cottonwood stands. All of these observations were in forested stands adjacent to open sagelands or meadows. In 3 cases, we saw adults foraging over the open, sage-dominated habitat. Singing males were found in old growth cottonwood and in Douglas fir; one nest was located in a cottonwood. In 2 cases where nests were presumably located, the Douglas fir stands featured mature but stagnant trees with $\mathrm{DBH}$ of 7 to 9 inches and tree canopy coverage of $60-75 \%$, with a dense shrub understory. The third stand featured Douglas fir of mixed age, old-growth to mature, interspersed with aspen and some lodgepole, and with dense shrub understory. Fledged broods were seen on three occasions in Douglas fir forests at the forest edge. The Douglas fir habitats were on dry slopes of $13 \%$ to $30 \%$. 


\section{Short-eared Owl, Asio flammeus}

The short-eared owl is primarily associated with open habitats such as prairie, tundra and wetlands, and agricultural areas such as hay meadows, pastures, and old fields (Clark 1975, Johnsgard 1988). This owl forages on small mammals which are found in these habitats. Winter roosts may be found in conifers or cottonwoods with similar characteristics to those used by long-eared owls, and may even be shared with longeared owls (Clark 1975). The short-eared owl is on the Audubon Society's blue list of declining species. This species is susceptible to the suite of ecological changes that can threaten many ground nesting birds, such as habitat alteration by factors such as fire or agricultural clearing and destruction by increased populations of foxes, skunks, ravens and other predators.

Short-eared owls were not detected in our samples, although we believe that they occur in open areas in the lower reaches of the study area. Population fluctuations may make this owl hard to find in some years.

\section{Northern Saw-Whet Owl, Aegolius acadicus}

The northern saw-whet owl uses forests and woodlands of all types (Cannings 1987, Palmer 1987). In the northern Rocky Mountains, nesting habitats include low elevation riparian habitats which are dominated by deciduous forests, mixed spruce-fir and Douglas-fir communities in the montane zone, and high elevation spruce-fir forests into the subalpine zone at elevations approaching $2300 \mathrm{~m}$ (Hayward and Garton 1988). As with other small, mostly nocturnal, cavity nesting owls, there is a notable lack of information on the population status of this species. The northern saw-whet owl nests in cavities excavated by northern flickers, hairy woodpeckers, man-made boxes and natural cavities. These owls often nest in aspen or cottonwoods.

The northern saw-whet was the most commonly detected of the small owls within our study area. This species was heard singing in upper elevations of the study area in forested stands adjacent to the riparian corridor, 3 records in mature aspen, and 7 records in Douglas fir. The fir stands were mixed-age on northern exposed slopes in tributary canyons, with canopy closures of $60-90 \%$. Shrub understory was generally dense.

\section{Northern Pigmy Owl, Glaucidium gnoma}

The northern pygmy owl is a resident of forested habitat from the foothills to higher elevations (Reynolds et al. 1989). The diminutive size of this species and its nocturnal habitats have resulted in few nests being found and thus, little information on this species exists (Holt and Norton 1986). Nests have been found in dead and live Douglasfir, ponderosa pine, aspen, grand fir and Western red cedar. Nest cavities used by pygmy owls have been excavated by sapsuckers and northern flickers. Nests may be found near openings such as meadows, partially timbered sites or wetlands (Reynolds 
et al. 1989). Such locations are thought to be associated with foraging habitat. They are typically not found in continuous forests, but near clearings, meadows, open water or other such openings (Verner and Boss 1980). This owl is associated with low elevation habitat but does range into higher elevation mountain areas (Reynolds et al. 1989). Breeding territories are thought to course natural topographic features such as ridges.

During the nesting seasons, we have detected northern pigmy owls within the study area on two occasions, once within and once outside of a designated sample quadrat. Both observations were in Douglas fir habitats which feature large, older growth trees interspersed with aspen stands. Aspen and fir snags were located, but no occupied nesting cavities were found.

The northern pigmy owl is not thought to be migratory, although they may undergo an elevational shift in habitat between summer and winter. We have seen pigmy owls in cottonwood bottoms along the Snake River during winter.

\section{Western Screech Owl, Otus kennicottii}

The western screech owl is generally associated with deciduous tree stands in open country, especially riparian hardwoods (cottonwood) bottoms. In central Idaho, Hayward (1983) noted a strong preference for cottonwood river bottoms. Nearby open grassland habitats were used for foraging. These small owls nest in cavities, in woodpecker holes or natural cavities. They sometimes use flicker holes in deciduous trees along stream sides. They also roost against the boles of cottonwoods where their gray coloration is an effective disguise. They often roost in conifers within cottonwood forests. Johnson et al. (1979) reported that western screech owl pairs nesting in riparian forests may be separated by as little as $50 \mathrm{~m}(164 \mathrm{ft}$.). Territories may be separated by much greater distances.

We did not detect any western screech owls despite many searches in sample areas, but have heard these owls in mixed age and old-growth cottonwood habitats near Heise.

\section{Flammulated Ow1, Otus flammeolus}

The flammulated owl is associated with mid-elevational open grown Douglas fir and aspen forests, usually on dry south facing slopes, at this latitude (Reynolds and Linkhart 1987). This species is a secondary cavity nester in cavities excavated by northern flickers and sapsuckers (Bull et al. 1990). Flammulated owls forage primarily upon insects, often upon beetles and noctuid moths, prey which may be more abundant in dry sites (Goggan 1986, Howie and Ritcey 1987, Reynolds and Linkhart 1987). Open growth forests that favor aerial insect hawking are thought to be an important habitat feature.

We have recorded 6 records of singing, and presumably nesting, flammulated owls, all in Douglas fir samples that featured mixed aspen. Five of these records were within the 
same expansive Douglas fir covered slope, with the other observation in a very similar stand. These stands are dominated by mixed age Douglas fir, with many fir snags and interspersed aspen stands. Canopy cover in these stands is highly variable owing to the interspersion of many openings, with overstory coverage in forested areas ranging from $50-100 \%$. Shrub understory is generally dense with diverse species, although some slopes are grass covered. Lodgepole pine stands are also featured in the areas.

\section{Great Gray Owl, Strix nebulosa}

Over their range in the northern and middle Rocky Mountains, great gray owls nest in a variety of forested habitats. Two habitat features common to these habitats are nest sites in mature or old-growth forest stands, and nearby openings for foraging (Habeck 1993). Nesting area habitats are always found within forested stands, and usually in stands with canopy closure greater than 60\% (Nero 1980, Bull and Henjum 1990). Openings vary from marshes to clearcuts. In east-central Idaho, southwestern Montana, and the Greater Yellowstone Area, most observations of great gray owls were in the lodgepole pine/Douglas fir/aspen zone (Franklin 1987, Whitfield et al. 1995). Most of the nests reported by Franklin (1987) were in Douglas-fir forests, with nests most commonly in Douglas fir and lodgepole pine. Aspen are occasionally used.

Great gray owls do not build nests; nest structures are usually old hawk (usually goshawk) or raven stick nests, depressions in the tops of broken-topped snags, or dwarf-mistletoe platforms (Nero 1980, Mikkola 1983, Franklin 1988). Thus, great gray owl's are dependent upon habitats that support goshawks and other stick-nest builders, or feature large snags. Young great grays require forest stands with small, deformed, or leaning trees (Franklin 1987, 1988). During summer, juveniles avoid sunlight and seek shade and security cover by frequenting trees with a dense canopy (Whitfield and Gaffney 1997).

We did not detect any great gray owls within our study area. Great grays are known to nest near the study area in adjacent forested areas. Great grays are suspected to winter within the riparian cottonwood bottoms during years when snowfall is above average in higher elevations.

\section{Barred Owl, Strix varia}

Barred owls typically breed within dense, mature woodlands, varying from uplands to lowland swamps, but especially wetland areas in deep woods (Nicholls and Warner 1972, Elody and Sloan 1985). The barred owl is a forest-dependent owl, and in areas where forest habitats are relatively small in size, barred owls may be excluded by much larger great horned owls. Nesting territories are usually in mature and dense mixed deciduous/conifer forests, often near water (Bosakowski et al. 1987). Nests are most often in a cavity in a large tree (roughly $50 \mathrm{~cm}$ dbh or larger), often in a deciduous tree. The owls use natural cavities or old squirrel or hawk nests. Often nests are near forest 
openings, and sometimes in the tops of hollowed tree stubs. Day roosts are typically in areas of maximum daytime concealment in densely foliated trees.

We did not detect any barred owls within the study area. However, barred owl range changes in recent years make it likely that this species will appear with the Snake River corridor.

\section{Boreal Owl, Aegolius funereus}

Boreal owls probably do not nest within our study area. This species is usually associated with higher elevation subalpine fir forest types, or mixed conifer and aspen (Hayward et al. 1993). Boreal owls are secondary cavity nesters.

Boreal owls are known to nest near the study area corridor, but at higher elevations. We detected a boreal owl in the cottonwood bottom below Dry Canyon in late fall, and suspect that this habitat may be used by wintering boreal owls.

\section{Burrowing Owl, Athene cunicularia}

Within this region, burrowing owls are found in isolated colonies in open plain habitats (Olenick 1989). Burrowing owls typically nest in flat pasture or grass lands where burrows are available (Johnsgard 1988).

We did not detect burrowing owls. They might be expected in the area's dryer habitats.

\section{Winter Raptor Observations}

We have not extensively studied the value of riparian cottonwood stands within the study area for wintering birds of prey. However, we have observed most of the species that do winter in this local within the cottonwood bottoms along the South Fork and Henry's Fork of the Snake River. Species we have observed in this habitat in winter include bald eagles, golden eagles, northern goshawk, northern pigmy owl, long-eared owl, and boreal owl. Great gray owls are found in the riparian bottom upriver of the study area on the Henry's Fork, and likely winter in the bottomlands along the upper South Fork as well.

The canyon reach of the South Fork represents a narrow corridor of relatively open habitat in winter. The lower reaches of the South Fork and Henry's Fork represent the only strips of largely forested habitat available within open, developed farm and recreational lands. As such, these habitats may have premium value for wintering wildlife. Because mortality of young fledglings is generally high for most species of birds of prey, survivorship of more advanced fledglings, those that survive the first few months, and certainly of adults, is of premium importance to long-term population sustainability. Thus, quality winter habitats found within the study area may be very important for those raptors that remain at this latitude year around. 
VII. Literature Review: Effects of Recreational Activities on Birds of Prey.

\section{Introduction}

As leisure time and disposable income have increased, and transportation has improved, public demand for recreational opportunities has also been on the rise. Fishing and non-consumptive recreational activities are projected to increase $63 \%$ to $142 \%$ over the next 50 years (Flather and Cordell 1995). In response to this public interest, many land management agencies have increased their attention on recreation resources, including wildlife viewing programs. At the same time, there is a trend toward less recreational opportunity and access on private lands. These factors add up to increased pressure on public lands to provide recreation opportunities.

River corridors and lakes are key recreation destinations. The Snake River corridor, our study area, is certainly a primary recreation destination in this region. Riparian corridors, such as the South Fork, are also recognized as some of the most rare and thus most crucial wildlife habitats in the western United States (Behnke 1979, Carothers 1977). For example, the South Fork of the Snake River supports the highest density of nesting bald eagles in Idaho, and is home to a greater diversity of wildlife species than any other habitat in the region.

Recreation surveys performed between 1980 and 1992 on the South Fork of the Snake River estimated recreation use and identified recreational visitor profiles (USDI and USDA 1991, Pratt 1992). The South Fork was the final destination of an estimated 225,000 visits annually. Recreational visitor use and access were split between boaters $(57 \%)$ and those recreating from the shore $(43 \%)$. The season of use extends from May through November and closely follows the fishing season. The peak period of recreational use in the canyon portion of the South Fork is during the trout fly hatch, which lasts for two weeks in July. The season of use on the lower portions of the River (Heise to Roberts Bridge) extends from March to November. The 61 mile stretch of the Snake River from Palisades Dam to it's confluence with the Henry's Fork is accessible to the everyday boater and hiker, and is striking in its natural beauty and wildlife bounty. It is within this narrow ribbon of important habitat that people and wildlife come face to face.

In part because recreational activities often take place over large areas, there is a perception that recreational impacts are benign to wildlife (Flather and Cordell 1995). Recently, it has become more widely accepted that wildlife is impacted directly and indirectly by recreational activities. The actual impacts, their causes and results, however, are not well understood (Knight and Cole 1995). This literature review of the impacts of recreational activities on wildlife, is conducted in the interest of the 19 species of raptors that reside within the Snake River Study Area. 


\section{$\underline{\text { Methods }}$}

We reviewed published and unpublished works that address human disturbance on birds of prey. Much of the older literature and research looked at effects of human presence, and was not specific to recreational activities. We included those papers which had findings applicable to our topic. Many of the effects upon raptors are related to the presence of people, without regard to the type of human activity. For example, a disturbed raptor may not differentiate between humans taking water samples or humans fishing, walking to work or hiking. Those few papers specific to recreational effects upon raptors have focused on a few species, the bald eagle being most often studied. No literature was found that addressed human disturbance effects on owls. The references section includes some papers that, although not cited, do contain pertinent information on recreation effects.

\section{Literature Findings}

After reviewing 536 references on the effects of non-consumptive recreation activities to wildlife, Boyle and Samson (1985) concluded that human impacts include direct mortality, habitat alteration and disturbance. Knight and Cole (1995) added pollution of wildlife environments and systems as another possible effect of human presence. The most immediate response of wildlife to these impacts is either death (exploitation) or a change in behavior. Knight and Cole (1995) go on to describe the long term effects of human disturbance to individuals, populations and communities (Figure 1).

The direct effects of these impacts are easily identified, such as the permanent loss of an individual animal, loss of a nest tree, or short term displacement of individuals. Direct effects are often more readily addressed and mitigated than indirect effects during project analysis. Many direct effects impact individual animals or family groups. However, even short term impacts to an individual may eventually impact an entire population or animal community over a long period of time (Cole and Landres 1995). 
Causes of impact:

Immediate

Response:

Long-term effects on

a. Individuals:

b. Populations:

c. Communities:

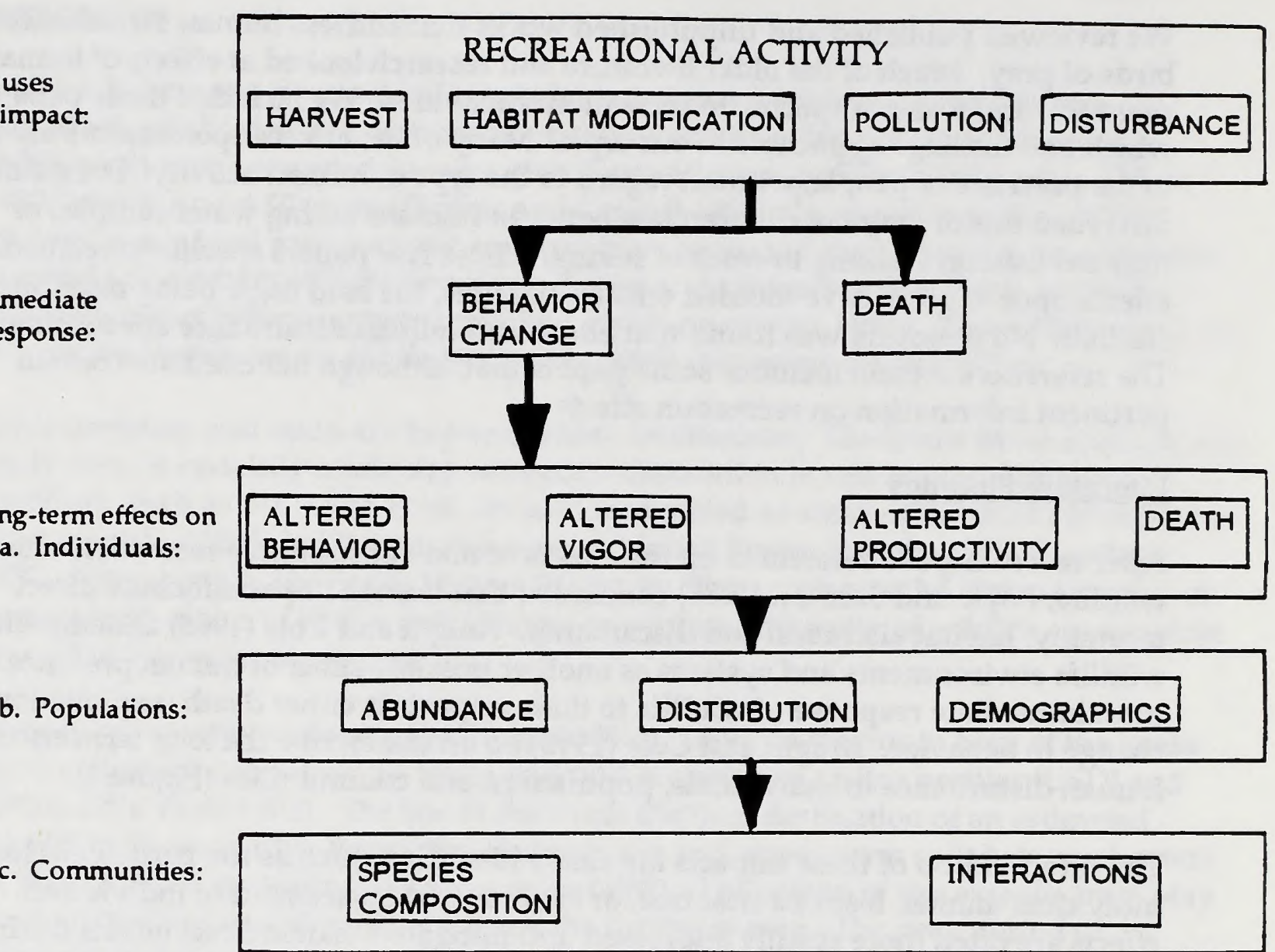

\section{RECREATIONAL ACTIVITY}

HABITAT MODIFICATION

Figure 7. Wildlife responses to recreational activities, a conceptual model (from Knight and Cole 1991)

Cole and Landres (1995) reviewed the literature on indirect effects of recreation on wildlife, and noted that virtually all recreational activities alter some soil, vegetation and aquatic system characteristics. Habitat alterations ultimately influence the behavior, survival, reproduction and/or distribution of wildlife by affecting their food and space. Human presence, even in the absence of habitat alteration, is known to cause bird displacement, and reduction in reproduction and survival. For example, even low levels of intrusion have resulted in reduced primary singing in passerine birds. Primary singing is used to attract mates, secure territories and maintain pair bonds (Gutzwiller et. al. 1997). This type of impact can ultimately effect reproductive success. 
An important point made by Cole and Landres (1995) is that, over a long period of time, effects on individual animals will eventually impact populations, communities and ecosystems. They also note that 1 ) indirect impacts are inevitable wherever and whenever recreational activities occur; and 2) indirect impacts generally occur for a long period of time, with effects that are long-lasting and may occur after a time lag. These qualities may make timing restrictions and user education programs relatively ineffective mitigation measures against ongoing indirect effects.

If recreational impacts affect the density and distribution of species which functionally dominate a system or community, the impacts can have severe long-term effects (Cole and Landres 1995). This observation is pertinent to raptors, because they reside at or near the top of food chains. Skagen et al. (1991) noted an example of this effect when the presence of anglers along a river resulted in a decline in bald eagles. This decline meant less food availability for other scavenging birds, which relied on a large bird like the bald eagle to open carcasses.

An example of a reverse form of "trophic cascade" was the displacement of bald eagles from McDonald Creek in Glacier National Park. Introduction of non-native opossum shrimp in the Flathead River-Lake ecosystem caused the collapse of the kokanee salmon population, and in turn, displaced bald eagles that had traditionally stopped during fall migration (Spencer et al. 1991). Bald eagle counts declined from 639 birds, tallied in a single count in 1981, to 25 birds seen in 1989. The indirect effect of this displacement is the increased potential of bald eagle mortality during migration and winter, especially to juvenile birds, if equitable alternate foods are not available (McClelland et al. 1983).

The magnitude of an animal's response to the impacting activity is influenced by characteristics of the disturbance and the individual animal. Factors such as timing, type, intensity, frequency, duration, predictability, extant and location of the disturbance can influence the severity of the impact. For example, disturbances to birds of prey during nest building and incubation have resulted in more reproductive failures than disturbances during the nestling period (Knight and Skagen 1988). Nest site abandonment, resulting in lower reproductive success, has been documented for osprey and ferruginous hawk (Dunstan 1968, Swenson 1979, Van Daele and Van Daele 1982, White and Thurow 1985). Short-term displacement during the nesting period can increase the vulnerability of eggs or nestlings to predation (Bortolotti et al. 1984, Fyfe and Olendorff 1976). Any displacement can affect the vigor of the individual through decreased energy gain, if the bird was displaced while foraging, or forced to increase energy expenditure (Stalmaster 1983). Reduced food intake or increased energy expenditure during the breeding period can impact the year's reproductive success (Swenson 1975, White and Thurow 1985).

Many researchers have noted specific "distances of tolerance" beyond which most individuals studied are displaced by approaching people (Holmes et al. 1993, Grubb et al. 1992, Fraser et al. 1985, Knight and Knight 1984, Russell et al. 1980, Whitfield and 
Maj 1995). Bald eagles responded most to human disturbances originating from water and gravel bars, and to a lesser degree from land-related disturbances (Stalmaster and Newman 1978). Even subtleties such as a direct approach versus a tangential approach resulted in different responses from birds (Young 1981). People walking have typically generated more negative responses from wildlife than people approaching in vehicles (Holmes et al. 1993, Klein 1993). However, mechanized forms of recreation have many side or indirect effects such as destruction and trampling of vegetation and ground, which can affect prey composition and abundance, and noise and other environmental pollutants (Bury 1978).

Factors such as previous exposure to disturbance, individual size, age, and color, group size and composition, and nutritional state of the individual also influence the response of the animal to disturbances (Holmes et al. 1993, Skagen et al. 1991, Knight et al. 1989, Dunne et al. 1988, Clark and Wheeler 1987, Stewart and Newman 1978). Wintering raptors, including rough-legged hawks, kestrels, and ferruginous hawks, responded differently to disturbance depending on their spatial context (Holmes et al. 1993). Birds closer to roads displaced at greater distances and ground perched birds flushed at greater distances than those perched higher or away from roads. Birds found along paved roads have been described as habituated to typical vehicle disturbances. It has been suggested that this response may be that more tolerant birds use more disturbed sites (Fraser et al. 1985, Buehler et al. 1991, McGarigal et al. 1991).

Knight et al. (1987) believe that in areas where direct persecution is not a problem, birds that habituate to human activity have the adaptive edge in pursuit of their life needs, food and space. With both passerines and raptors, flushing distances increase with body size (Holmes et al. 1993, Cooke 1980). Large birds have been noted to flush at longer distances than small-sized birds. This may be because large birds are greater targets of persecution, or because smaller-sized birds are more hesitant to flush because they expend more energy relative to larger birds because of their larger surface area to body mass ratio.

\section{Summary and Conclusions}

It is fair to acknowledge that it is difficult to measure the impact of human disturbances upon birds of prey. Raptor species generally have large home ranges, low population densities, and high mobility. Many species, e.g. nocturnal raptors, are inconspicuous by their nature. Raptor reproduction, which may depend upon many conditions such as annual climate and prey base fluctuations, can vary widely from year and to year. There is also great variability in individual animal response to human presence, variability which appears to be related to many factors. So where does this leave the manager who wants to apply the most appropriate strategy to minimize human disturbance on birds of prey?

Two primary approaches which have been used to minimize recreational impacts on raptors are: 1) prevent people from entering certain areas or zones, and 2) use 
management strategies that allow both people and raptors to coexist (Olendorff and Kochert 1977). This later approach requires species-specific information on habitat relationships and response to recreational activities.

The combination of both approaches are currently in place on the South Fork of the Snake River (USDI and USDA 1991). Spatial and temporal restrictions have been placed at bald eagle nest sites along the river. Between Conant and Black Canyon, camping is restricted to 15 designated sites. This approach attempts to restrict inappropriate and disturbing activities during the crucial nesting period, and also serves to protect and potentially maintain certain habitat conditions and features. The success of this approach is measured in productivity and long-term displacement or abandonment of nest sites. We caution that using productivity or abandonment as a sole measure of success is an "all or nothing" measure. Until the critical threshold is reached and the birds have reproductive failure or leave the area, there is no prior measure of the impact. Studies have been conducted that looked at disturbance-induced changes in breeding ecology of bald eagles (Young 1980). Such studies are labor and resource intensive, but can disclose important information.

Research has found that the amount of human use and amount of impact to wildlife are related in a curvilinear manner. As use levels increase, additional use of the same type may have less and less impact. Cole and Landres (1995) suggest that, in some cases, limiting use levels to reduce indirect impacts may only be effective when use is virtually eliminated. Conservation of especially rare and vulnerable raptorial species, such as the California condor, has required setting aside large areas where people are excluded and management is designed to favor the species. This approach is considered extreme and undesirable, but may be the necessary approach to conserving rare or especially vulnerable species and habitats.

Development of proper management strategy is hampered by complexities that fog our understanding of the cause and effects of disturbances on wildlife. Gutzwiller (1991, 1993) is a strong proponent of experimental research with control of certain humanrelated variables. Controlled, experimental approaches allow a more direct evaluation of cause and effect. Field experiments are a realistic approach to increasing our understanding of impact processes (Walters and Hollings 1990). Although this approach may require a greater immediate outlay of resources, and some loss of the birds under study, it is probably the most expedient approach to answering cause and effect questions.

Evaluation of recreational activities and their impacts to raptors of the South Fork of the Snake is timely, and should be an on-going process. The South Fork continues to grow in popularity for recreational groups, as more people, in more and different ways, visit the river. Additionally, substantial human development and habitat changes are taking place on adjacent private lands. These factors are likely interacting synergistically to effect birds of prey. 
Species which have their entire home range along the long and relatively narrow river corridor are particularly susceptible to fragmentation, widespread disturbance and additive impacts. The bald eagle fits this profile. In our judgment, the BLM's approach to research and management practices directed towards the bald eagle has been quite appropriate. Many other species with more general habitat needs focus their activities along this corridor owing to habitat loss on lands adjacent to the river corridor.

Cavity nesting raptors, such as kestrels, and northern pygmy, flammulated, western screech and saw-whet owls, are an example of a group of species which react to human activities in a multitude of ways. These birds are impacted by loss of suitable cavity nesting trees, unavailability of cavities with the increase of competing species, which often increase in the presence of man (Craighead and Mindell 1981), and reduced prey and direct poisoning by insecticides used on adjacent private lands, among other factors.

Birds of prey are one of the important resources that bring people to the South Fork, and a source of recreational enjoyment. More importantly, the raptorial birds that use the river corridor have tremendous intrinsic value in the ecological functions of the entire biological community. Long-term conservation of this resource, for recreational and intrinsic values, will require due diligence. Cooperative management of the Snake River should continue to include all local, state and federal agencies and interested nongovernmental entities. 


\section{General}

\section{REFERENCES}

Greater Yellowstone Bald Eagle Working Group. 1996. Greater Yellowstone bald eagle managment plan: 1995 Update. Greater Yellowstone Bald Eagle Working Group, Wyo. Game and Fish Dept., Lander, WY, 47 pp.

McKenzie, N.L., A.C. Robinson, and L. Belbin. 1991. Biogeographic suvey of the Nullarbor District, Australia. Pp. 109-126 in Margules and M.P. Austin, eds. Nature conservation: cost effective biological surveys and data analysis, Australia, CSIRO, East Melbourne.

Ulliman, J.J., R. Balice, A. Fahsi, S. Choung, and G. Navarro. 1991. Vegetation mapping and monitoring of the South Fork of the Snake River. Final report to the Boise Field Office, U.S.D.I. Fish and Wild. Ser., Univ. of Idaho, Moscow, 13 pp.

USDI, Bureau of Land Management and USDA Forest Service. 1991. Snake River Activity/Operations Plan. 101 pp. + append. and maps.

Whitfield, M. B., S. L. Austin, and G. Tomb. 1991. Continental Idaho Population Unit Interim Report. Idaho bald eagle research project, Greater Yellowstone Ecosystem, Bureau of Land Managment, Idaho Falls, Idaho, 104 pp.

Whitfield, M. B. 1993. South Fork Snake River, final report. Idaho Bald Eagle Research Project. U. S. D. I. Bur. of Land Manage., Idaho Falls, Idaho, 92 pp. plus appendices.

Whitfield, M.B., M.E. Maj. and P. Munholland. 1995. Inventory and monitoring of bald eagles and other raptorial birds of the Snake River, Idaho Bur. Land Manage. Tech. Bull. No.95-12. 75 pp.

Whitfield, M.B. and M.E. Maj. 1996. Inventory and monitoring of bald eagles and other raptorial birds of the Snake River, Idaho Bur. Land Manage. Tech. Bull. No.96-12. 53 pp.

Whitfield, M.B., M. Maj, J. Naderman, J. Gardetto, K. Rice, D. Trochta, R. Welch, B. Aber, and B. Alford. 1996. Annual Bald Eagle Productivity, Final Report. Idaho Portion of the Greater Yellowstone Ecosystem. Idaho/GYE Bald Eagle Research Project, U. S. Bur. of Land Manage., U. S. Forest Service, Targhee National Forest, Idaho Depart. of Fish and Game and Northern Rockies Conservation Cooperative, Idaho Falls, Idaho, 16 pp. plus tables.

Whitfield, M.B., S. Austin, J. Copeland, J. Naderman, J. Gardetto, K. Rice, D. Trochta, R. Welch, B. Aber, and B. Alford. 1997. Annual Bald Eagle Productivity, Final Report. Idaho Portion of the Greater Yellowstone Ecosystem. Idaho/GYE Bald Eagle Research Project, U. S. Bur. of Land Manage., U. S. Forest Service, Targhee National Forest, Idaho Depart. of Fish and Game and Northern Rockies Conservation Cooperative, Idaho Falls, Idaho, 19 pp. plus tables. 


\section{Raptor Habitats}

Austing, G.R. and J.B. Holt, Jr. 1966. The world of the great horned owl. Lippencott, Philadelphia.

Balgooyen, T.G. 1976. Behavior and ecology of the American kestrel. Univ. Ca. Publ. Zool 103:1-83.

Bechard, M.J. 1982. Effect of vegetative cover of foraging site selection by Swainson's hawk. Condor 84: 153-159.

Beecham, J.J. and M.N. Kochert. 1975. Golden eagle breeding biology, Idaho. Wilson Bull. 87:506-513.

Bent, A.C. 1938. Life histories of North American birds of prey, pt. 2, U.S. Natl. Mus. Bull. No. 170 .

Bosakowski, T., R. Speiser, and J. Benzinger 1987. Distribution, density, and habitat relationships of the barred owl in northern New Jersey. Pp. 135-143 in Nero, R. W., R. J. Clark, R. J. Knapton, and R. H. Hamre eds., Biology and conservation of northern forest owls, Symposium Proceedings., U.S.D.A. Forest Ser., Gen. Tech. Report RM-142.

Bull, E.L. and M.G. Henjum. 1990. Ecology of the Great Gray Owl. Gen. Tech. Rep. PNWGTR-265, USDA Forest Service, Pacific Northwest Research Sta., Portland, Or, 39 pp.

Bull, E.L., A.L. Wright, and M.G. Henjum. 1990. Nesting habitat of flammulated owls in Oregon. J. Raptor Res. 24: 52-55.

Bull, E.L., A.L. Wright, and M.G. Henjum. 1989. Nesting and diet of long-eared owls in conifer forests, Oregon. Condor 91: 908-912.

Cade, T.J. 1992. The falcons of the world. Cornell Univ. Press, Ithaca, N.Y., 188 pp.

Cannings, R.J. 1987. The breeding biology of the northern saw-whet owls in southern British Columbia. Pp. 193-198 in Nero, R. W., R.J. Clark, R.J. Knapton, and R.H. Hamre. ed., Biology and conservation of northern forest owls, Symposium Proceedings, USDA Forest Service, Gen. Tech. Report RM-142.

Clark, R.J. 1975. A field study of the short-eared owl (Otus flammeus) (Pontoppidan) in North America. Wild. Monogr. 47:1-67.

Coleman, J.S. and J.D. Fraser. 1989. Habitat use and home ranges of black and turkey vultures. J. Wildl. Manage. 53: 782-792

Cottrell, M.J. 1981. Resource partitioning and reproductive success of hawks (Buteo spp.) in an Oregon prairie. M.S. Thesis, Oregon St. Univ., Corvallis.

Craighead, J.J. and F.C. Craighead, Jr. 1956. Hawks, owls and wildlife. Stackpole Co., Harrisburg, $\mathrm{Pa}$.

Craig, E.H., T.H. Craig, and L.R. Powers. 1988. Activity patterns and home-range use of nesting long-eared owls. Wilson Bull. 100: 204-213. 
Dunkle, S.W. 1977. Swainson's hawks in Wyoming. Auk 94:65-71.

Elody, B.I. and N.F. Sloan. 1985. Movements and habitat use of barred owls in the Huron Mountains of Marquette County, Michigan, as determined by radiotelemetry. Jack-Pine Warbler 63:3-8.

Franklin, A.B. 1987. Breeding biology of the Great Gray Owl in southeastern Idaho and northwestern Wyoming. M.S. thesis, Humboldt State Univ., Humboldt, CA. 83pp.

Franklin, A.B. 1988. Breeding biology of the Great Gray Owl in southeastern Idaho and northwestern Wyoming. Condor 90: 689-696.

Fitzner, R.E. 1978. The ecology and behavior of the Swainson's hawk (Buteo swainsoni) in southeastern Washington. Ph.D. diss., Washington St. Univ., Pullman.

Gates, J.M. 1972. Red-tailed hawk populations and ecology in east central Wisconsin. Wilson Bull. 84: 421-433.

Goggans, R. 1986. Habitat use by flammulated owls in northeastern Oregon. Thesis. Oregon State Univ., Corvalis, OR.

Habeck, J.R. 1994. Dynamics of forest communities used by Great Gray Owls. Pp. 176-210 in G.D. Hayward and J. Verner eds., Flammulate, boreal, and Great Gray Owls in the United States: a technical conservation assessment, Gen. Tech. Rep. RM-253, Rocky Mnt. For. and Ra. Exp. Sta. and Rocky Mnt. Region, USDA Forest Service, Fort Collins, Co., 214 pp.

Harmata, A. and B. Oakleaf. 1992. Bald eagles in the Greater Yellowstone Ecosystem: an ecological study with emphasis on the Snake River, Wyoming. Wyoming Dept. Game and Fish, Cheyenne, $232 \mathrm{pp}$.

Hayward, G.D. 1983. Resource partitioning among six forest owls in the River of No Return Wilderness, Idaho. M. S. Thesis, Univ. Idaho, Moscow. 132 pp.

Hayward, G.D. and E.O. Garton. 1988. Resource partitioning among forest owls in the River of No Return Wilderness, Idaho. Oceoligia 75: 253-265.

Hayward, G.D., P.H. Hayward, and E.O. Garton. 1993. Ecology of boreal owls in the northern Rocky Mountains, USA. Wildlife Monographs 124: 1-59.

Hobbie, J.E., and T.J. Cade. 1962. Golden eagle breeding in Alaska. Condor 64:235-237.

Holt, D.W. and S.M. Leasure. 1993. Short-eared Owl. The birds of North Amercica, No. 62, The Academy of Natural Sciences of Philadelphia, $21 \mathrm{pp}$.

Holt, D.W., and W.D. Norton. 1986. Observations of nesting northern pygmy-owls. J. Raptor Res. 20:39-41.

Howell, J., B. Smith, J.B. Holt, and D.R. Osborne. 1978. Red-tailed hawk habitat and productivity. Bird-Banding 49:162-171. 
Howie, R.R. and R. Ritcey. 1987. Distribution, habitat selection, and densities of flammulated owls in British Columbia. Pp. 249-254 in Nero, R.W., R.J. Clark, R.J. Knapton, and R.H. Hamre eds., Biology and conservation of northern forest owls, Symposium Proceedings, USDA For. Service, Gen. Tech. Report RM-142.

Janes, S.W. 1985. Habitat selection in raptorial birds. Pp. 159-199 in M. L. Cody ed., Habitat selection in birds, Academic Press, New York.

Johnsgard, P.A. 1988. North American owls: biology and natural history. Smithsonian Inst. Press, Wash., D. C.

Johnsgard, P.A. 1990. Hawks, eagles, and falcons of North America. Smithsonian Inst. Press, Washington, D.C. 404 pp.

Johnson, S.J. 1975. Productivity of the red-tailed hawk in southwestern Montana. Auk 92: 732-736.

Johnson, R.R., L.T. Haight, and J.M. Simpson. 1979. Owl populations and species status in the southwestern United States. Pp 40-59 in P. Schaeffer and S. Ehlers, eds., Owls of the West: their ecology and conservation. Western Education Center, National Audubon Soc., Tiburon, CA.

Joy, S.M., R.T. Reynolds, R.L. Knight, and R.W. Hoffman. 1994. Feeding ecology of sharpshinned hawks nesting in deciduous and coniferous forests in Colorado. Condor 96:455-467.

Marks, J.S. 1986. Nest site characteristics and reproductive success of long-eared owls in southwestern Idaho. Wilson Bull. 98: 547-560.

Marti, C.D., and C.E. Braun. 1975. Prairie falcons in tundra habitats, Colorado. Condor 77: 213-214.

Martin, J.W. 1987. Behavior and habitat use of breeding northern harriers in southwestern Idaho. J.Raptor Res. 21:57-66.

McGahan, J. 1968. Ecology of the golden eagle. Auk 85:1-12.

Mikkola, H. 1983. Owls of Europe. Buteo Books, Vermillion, S. Dakota. 397pp.

Moore, K.R. and C.J. Henny. 1983. Nest site characteristics of three coexisting accipiter hawks in Northeastern Oregon. J. Raptor Res. 17: 65-76.

Nero, R.W. 1980. The Great Gray Owl-phantom of the northem forest. Smithsonian Institution Press, Washington, D.C., 167 pp.

Nicholls, T.H. and D.W. Warner. 1972. Barred owl habitat use as determined by radiotelemetry. J. Wild. Manage. 36:213-224.

Olenick, B.E. 1989. Burrowing Owl. Pp. 79-81 in Clark, T.W., et al., eds. Rare, sensitive, and threatened species of the Greater Yellowstone Ecosystem. Northern Rockies

Conservation Cooperative, Montana Natural Heritage Program, The Nature Conservancy, and Mountain West Envi. Services, Jackson, WY, 153 pp. 
Palmer, D.A. 1987. Habitat selection, movements and activity of boreal and saw-whet owls. J. Raptor Res. 21: 45.

Patla, S. 1991. Northern goshawk monitoring project report \#2. Targhee National Forest, St. Anthony, ID, 43 pp. plus app.

Pattee, O.H. and S.R. Wilbur. 1987. Turkey vultures and California condors. Pp. 61-65 in Proceedings of the western raptor management symposium and workshop. National Wildlife Fed., Boise Idaho. Scientific and Technical Series No. 12

Petersen, L. 1979. Ecology of great horned owls and red-tailed hawks in southeastern Wisconsin. Wisc. Dept. Nat. Resour. Tech. Bull. No. 111:1-63.

Platt, J.B. 1976. Sharp-shinned hawk nesting and nest site selection in Utah. Condor 78:102-10

Poole, A.F. 1989. Ospreys: a natural and unnatural history. Cambridge University Press, New York, $246 \mathrm{pp}$.

Reynolds, R.T. 1983. Management of western coniferous forest habitat for nesting accipiter hawks. USDA Forest Service Gen. Tech. Report RM-102 7pp.

Reynolds, R.T. 1989. Accipiters. Pp. 92-101 in Proc. western raptor management symposium and workshop. Natl. Wildl. Fed., Washington, D.C.

Reynolds, R.T., E.C. Meslow, and H.M. Wight. 1982. Nesting habitat of coexisting Accipiter in Oregon. J. of Wildlife Manage. 46:124-138.

Reynolds, R.T., and H.M. Wight. 1978. Distribution, density, and productivity of accipiter hawks breeding in Oregon. Wilson Bull. 90: 182-196.

Reynolds, R.T. and B.D. Linkhart. 1987. The nesting biology of flammulated owls in Colorado Pp. 239-248 in Nero, R.W., R.J. Clark, R.J. Knapton, and R.H. Hamre eds., Biology and conservation of northern forest owls, Syposium Proceedings, USDA Forest Service, Gen. Tech. Report RM-142.

Reynolds, R.T., R.A. Ryder, and B.D. Linkhart. 1989. Small forest owls. Pp. 134-143 in Proc. western raptor management symposium and workshop. National Wildl. Fed. Washington D.C. 320 pp.

Rohner, C. and F.I. Doyle. 1992. Methods of locating great horned owl nests in the boreal forest. J.Raptor Res. 26:33-35.

Runde, D.E., and S.H. Anderson. 1986. Prairie falcon nest sites. Raptor Res. 20:21-28.

Sedgwick, J.A. and F.L. Knopf. 1990. Habitat relationships and nest site characteristics of cavity-nesting birds in cottonwood floodplains. J. Wild. Manage. 54:112-124.

Sherrod, S.K. 1978. Diets of North American Falconiformes. Raptor Res. 12: 49-121.

Sieg, C.H. and D.M. Becker. 1990. Nest-site habitat selected by merlins in Southeastern Montana. The Condor 92: 688-694. 
Smith, D.G., and J.R. Murphy. 1973. Breeding ecology of raptors in Utah. Brigham Young Univ. Sci. Bull. Biol. Ser. 18:1-76.

Steenhof, K., M.N. Kochert, and R.N. Lehman. 1991. Raptor nesting densities and reproductive success in the Snake River Birds of Prey Area, 1991. Pp. 13-36 in Steenhof, K. ed., Snake River Birds of Prey Research and Monitoring Annual Report, U.S.D.I. Bureau of Land Manage., Boise District, Boise, 261 pp.

Swenson, J.E. 1981. Status of the osprey in southeastern Montana before and after the construction of reservoirs. Western Birds 12:47-51.

Swenson, J. E., K.L. Alt, and R. L. Eng. 1986. Ecology of bald eagles in the Greater Yellowstone Ecosystem. Wildlife Society, Wildlife Monograph No. 95, 46 pp.

Thurow, T.L. and C.M. White. 1983. Nest site relationship between the ferruginous and Swainson's hawk. J. Field Omith. 54: 401-406.

Titus, K. and J. A. Mosher. 1981. Nest site habitat selected by woodland hawks in the central Appalachians. Auk 98: 270-281.

Van Daele, L.J., H.A. Van Daele, and D. R. Johnson. 1980. The status and management of ospreys nesting in Long Valley, Idaho. U.S. Water and Power Resources Service, Proj. Report, Univ. of Idaho, Moscow, 49 pp.

Verner, J. and A.S. Boss. 1980. Califormia wildlife and their habitats: Western Sierra Nevada. USDA, Forest Service, Gen. Tech. Report PWS-37.

Whitfield, M.B. 1993. South Fork Snake River, final report. Idaho Bald Eagle Research Project. U. S. D. I. Bur. of Land Manage., Idaho Falls, Idaho, 92 pp. plus appendices.

Whitfield, M.B., M. Gaffney, M. Gebhardt, C. Rigle, M. E. Maj, and A. Whitfield. 1996. Monitoring of Great Gray Owls, Targhee National Forest and Teton Valley Idaho/Wyoming. Targhee National Forest, St. Anthony, Id. 72 pp.

Whitfield, M.B. and M. Gaffney. 1997. Great gray owl breeding habitat use within altered forests, eastern Idaho and northwest Wyoming. Proceedings of the Second International Syposium: Biology and Conservation of Owls of the Northern Hemisphere, Winnipeg, Manitoba.

Woodbridge, B.B. 1987. Swainson's hawks and grazing in California. Proc. Ann. Meeting, Raptor Res. Found., Boise, Idaho.

\section{Recreation Effects on Birds of Prey:}

Ames, P.L. and G.S. Mersereau. 1964. Some factors in the decline of the osprey in Connecticut. Auk 81:173-185.

Anderson, D.W. and J.O. Keith. 1980. The human influence on seasbird nestig success: conservation implications. Biol. Conserv. 18:65-80.

Anthony, R.G., R.J. Steidl, and K. McGarigal. 1995. Recreation and bald eagles in the Pacific northwest. Pp. 223-242 in Wildlife and Recreationist, coexistence through management and research. (R.L. Knight and K.J. Gutzwiller, eds.). Island Press, Washington D.C. 
Behnke, R.J. 1979. Values and protection of riparian ecosystems. Pp. 164-167 in The mitigation symposium: a national workshop on mitigating losses of fish and wildlife habitats. (G.A. Swanson, tech. coord.). USDA Forest Service Gen. Tech. Rep. RM-65.

Blakesley, J.A. and K.P. Reese. 1988. Avian use of campground and non campground sites in riparian zones. Jour. Wildl. Manage. 52:399-402.

Bortolotti, G.R., J.M. Gerrard, P.N. Gerrard, and D.W.A. Whitfield. 1984. Minimizing investigator-induced disturbance to nesting bald eagles. Pp. 85-103 in The Bald Eagle in Canada (G.M. Gerrard and T.M. Ingram, eds.). Proc. Bald Eagle Days, Winnipeg.

Boyle, S.A. and F.B. Samson. 1985. Effects of non-consumptive recreation wildlife: A review. Wildlife Soc. Bull. 13:110-116.

Brown, J.H. and E.J. Heske. 1990. Control of a desert-grassland transition by a keystone rodent guild. Science 250:1705-1707.

Buehler, D.A., T.J. Mersmann, J.D. Fraser, and J.K.D. Seegar. 1991. Effects of human activity on bald eagle distribution on the northem Chesapeake Bay. J.Wildl. Manage. 55:282-290.

Bury, R.B. 1980. What we known and do not know about off-road vehicle impacts on wildlife. Pp. 110-122 in Off-road vehicle use: a management challenge (R.N.L. Andrews and P.F. Nowak, eds.). Conf. Proc. USDA, Office Environmental Quality, Washington, D.C.

Carothers, S.W. 1977. Importance, preservation and management of riparian habitat: an overview. Pp. 2-4 in Symposium on management of forest and range habitats for nongame birds. USDA Forest Serv. Gen. Tech. Rep. RM-43.

Clark, W.S. and B.K. wheeler. 1987. A field guide to hawks of North America. Houghton Mifflin Co., Boston, Mass. 198 pp.

Clevenger, G.A. and G.W. Workman. 1977. The effects of campgrounds on small mammals in Canyon lands and Arches National Parks, Utah. Trans. N. Am.. Wildl. and Nat. Res. Conf. 42:473-484.

Cole, D.N. and R.L. Knight. 1990. Impacts of recreation on biodiversity in wilderness. In Proceedings of a symposium on wilderness areas: their impact, 33-40. Logan, Utah: Utah State University.

Cole, D.N. and P.B. Landres. 1995. Indirect effects of recreationists on wildlife. Pp. 183-202 in Wildlife and Recreationist, coexistence through management and research. (R.L. Knight and K.J. Gutzwiller, eds.). Island Press, Washington D.C.

Cooke, A.S. 1980. Observations on how close certain passerine species will tolerate an approaching human in rural and suburban areas. Biol. Vonserv. 18:85-88.

Craighead, F.C., Jr. and D.P. Mindell. 1981. Nesting raptors in western Wyoming, 1947-1975. J. Wildl. Manage. 45:865-872.

Dunne, P., D.Sibley, and C. Sutton. 1988. Hawks in flight. Houghton Mifflin Co., Boston, Mass. 254 pp. 
Dunstan, T.C. 1968. Breeding success of osprey in Minnesota from 1963-1968. Loon 40:109-112.

Flather, C.H. and H.K. Cordell. 1995. Outdoor recreation: historical and anticipated trends. Pp. 3-16 in Wildlife and Recreationist, coexistence through management and research. (R.L. Knight and K.J. Gutzwiller, eds.). Island Press, Wash. D.C.

Frazer,J.D., L.D. Frenzel, and J.E. Mathisen. 1985. The impacts of human activities on breeding bald eagles in northcentral Minnesota. Jour. of Wildl. Manage. 49:585-592.

Fyfe, R.W. and R.R. Olendorff. 1976. Minimizing the dangers of nesting studies to rators and other sensitive species. Can. Wildl. Serv. Occas. Paper 2317 pp.

Gamauf, A. 1994. The influence of tourism on marsh harriers Circus aeruginosus in the Neudiedlersee-Seewinkel National Park, Austria, in Raptor Conservation Today (B.-U. Meyburg and R.D. Chancellor eds.). Pica Press, London.

Gerrard, P.N., J.M. Gerrard, and G.R. Bortolotti. 1984. The impact of road development and tourist access on a bald eagle population at Benard Lake, Saskatchewan. Pp. 160-165 in The Bald Eagle in Canada (G.M. Gerrard and T.M. Ingram, eds.). Proc. Bald Eagle Days, Winnipeg.

Grubb, T.G. and R.M. King. 1991. Assessing human disturbance of breeding bald eagles with classification tree models. J. Wildl. Manage. 55(3):500-511.

Grubb, T.G., W.W.Bowerman, J.P. Giesy, and G.A. Dawson. 1992. Responses of breeding bald eagles, Haliaeetus leucocephalis, to human activities in northcentral Michigan. Can. Field-Nat. Vol 106:443-453.

Gutzwiller, K.J. 1991. Assessing recreational impacts in wildlife: the value and design of experiments. Trans. N. Am. Wildl. and Nat. Res. Conf. 56:248-255.

Gutzwiller, K.J. 1993. Serial management experiments: an adaptive approach to reduce recreational impacts on wildlife. Trans. of the N. A. Wildlife and Natural Res. Conf. 58:528-536.

Gutzwiller, K.J., R.T. Wiedenmann, K.L. Clements, and S.H. Anderson. 1994. Effects of human intrusion on song occurrence and singing consistency in subalpine birds. Auk $111(1): 28-37$.

Gutzwiller, K.J., E.A. Kroese, S.H. Anderson, and C.A. Wilkens. 1997. Does human intrusion alter the seasonal timing of avian song during breeding periods. Auk 114(1):55-65.

Holmes, T.L., R.L. Knight, L.Stegall, and G.R. Craig. 1993. Responses of wintering grassland raptors to human disturbance. Wildl. Soc. Bull. 21:461-468.

Jackson, J.A. 1983. Nesting phenology, nest site selection, and reproductive success of black and turkey vulures. Pp. 245-270 in Vulture Biology and Management. ed. S.R. Wilbur and J.A. Jackson. Univ. of Calif. Press.

Johnsgard, P. A. 1990. Hawks, eagles, and falcons of North America. Smithsonian Inst. Press, Washington, D.C. 404 pp. 
Klein, M.L. 1993. Waterbird behavioral responses to human disturbances. Wild. Soc. Bull. 21:31-39.

Knight, R.L. 1984. Responses of nesting ravens to people in areas of different human densities Condor 86:345-346.

Knight, R.L. and S.K. Knight. 1984. Responses of wintering bald eagles to boating activities. Jour. Wildl. Manage. 48:999-1004.

Knight, R.L. and S.K. Skagen. 1988. Effects of recreational disturbance on birds of prey: a review. Pp. 355-359 in Proc. Southwest Raptor Management Symposium and Workshop (R.L. Glinski et al. eds.). Natl. Wildl. Fed., Washington, D.C.

Knight, R.L., D.E. Andersen, M.J. Bechard, and N.V. Marr. 1989. Geographic variation in nestdefense behavior of the red-tailed hawk Buteo jamaicensis. Ibis 131:22-26.

Knight, R.L. and D.N. Cole. 1991. Effects of recreational activity on wildlife in wildlands. Trans. N. Am. Wildl. and Nat. Res. Conf. 56:238-247.

Knight, R.L., D.P. Anderson, and N.V. Marr. 1991. Responses of an avian scavenging guild to anglers. Biol. Conservation 56:195-205.

Knight, R.L. and D.N. Cole. 1995. Wildlife responses to recreationists. Pp. 51-70 in Wildlife and Recreationist, coexistence through management and research. (R.L. Knight and K.J. Gutzwiller, eds.). Island Press, Washington D.C.

Knight, R.L. and D.N. Cole. 1995. Factors that influence wildlife responses to recreationists. Pp. 71-80 in Wildlife and Recreationist, coexistence through management and research.

(R.L. Knight and K.J. Gutzwiller, eds.). Island Press, Washington D.C.

Lanier, J.W., and R.A. Joseph. 1989. Managing human recreational impacts on hacked or freenesting peregrines. In Proc. of the northeast raptor management symposium and workshop, Pendelton, B.G., M.N. LeFranc Jr., M.B. Moss, C.E. Ruibal, M.A. Knighton and D.L. Krahe, eds. Natl. Wildl. Fed., Washington, D.C.

MacNab, J. 1983. Wildlife management as scientific experimentation. Wildl. Soc. Bull. $11: 397-401$.

McGarigal, K, R.G. Anthony, and F.B. Isaacs. 1991. Interactions of humans and bald eagles on the Columbia River estuary. Wildl. Monogr. 115:1-47.

Mathisen, J.E. 1968. Effects if human disturbance on nesting bald eagles. J. Wildl. Manage. 32(1):1-6.

Montopoli, G.J. and D.A. Anderson. 1991. A logistic model for the cumulative effects of human intervention on bald eagle habitat. J. Wildl. Manage. 55(2):290-293.

Olendorff, R.R. and M.N. Kochert. 1977. Land management for the conservation of birds of prey. Pp. 294-306 in Proc. world conference on birds of prey, Intl. Counc. Bird Preservation, (R.D. Chancellor, ed.). Vienna, Austria.

Olsen, J. and P. Olsen. 1980. Alleviating the impact of human disturbance on the breeding peregrine falcon II. Public and recreational lands. Corella. 4:54-57. 
Pomerantz, G.A., D.J. Decker, G.R. Goff, and K.G. Purdy. 1988. Assessing impact of recreation on wildlife: a classification scheme. Wildlife Soc. Bull. 16:58-62.

Poole, A. 1981. The effects of human disturbance on osprey reproductive success. Colonial Waterbirds. 4:20-27.

Postovit, H.R. and B.C. Postovit. 1987. Impacts and mitigation techniques. Pp. 183-213 in Raptor management techniques manual (B.G. Pendleton, B.A. Millsap, K.W. Cline and D.M. Bird (eds.). Natl. Wildl. Fed. Scientific and Tech. Series No. 10.

Pratt, J. 1992. Snake River visitor use study (Palisades Dam to Roberts and St. Anthony to Confluence). Prepared for BLM, Idaho Falls, Idaho. 71 pp. + appendices.

Ream, C.H. 1980. Impact of backcountry recreationists on wildlife: An annotated bibliography. USDA, For. Serv., Gen. Tech. Rep. INT-84. 62 pp.

Rusch, D.H., E.C. Meslow, P.H. Doerr, and L.B. Keith. 1972. Response of great horned owl populations to changing prey densities. J.Wildl. Manage. 36:282-295.

Russel, D. 1980. Occurrence and human disturbance sensitivity of wintering bald eagles on the Sauk and Suiattle rivers, Washington. Pp. 165-174 in Proc. of the washington bald eagle symposium (R.L. Knight, G.T. Allen, M.V. Stalmaster, and C.W. Servheen, eds.). The Nature Conservancy, Seattle, Washington.

Saab, V.A., C.E. Bock, T.D. Rich, and D.S. Dobkin. 1995. Livestock grazing effects in western North America. Pp. 311-353 in Ecology and management of neotropical migratory birds: a synthesis and review of critical issues. (T.E. Martin and D.M. Finch, eds.). Oxford Univ. Press, New York.

Skagen, S.K. 1980. Behavioral responses of wintering bald eagles to human activity on the Skagit River, Washington. Pp. 231-241 in Proceedings of the Washington Bald Eagle Symposium, Seattle, Washington (R.L. Knight, G.T. Allen, M.V. Stalmaster, and C.W Servheen,eds.). The Nature Conservancy, Seattle, Washington.

Skagen, S.K., R.L. Knight, and G.H. Orians. 1991. Human disturbance of an avian scavenging guild. Ecological Applications 1(2):215-225.

Smith, D.G., D.H. Ellis, and T.H. Johnson. 1988. Raptors and aircraft. Pp. 360-367 in Proceedings of the Southwest Raptor Management Symposium and Workshop. (R.L. Glinski et al., eds.). Nat. Wildl. Fed., Washington, D.C.

Snyder, H.A. and N.F.R. Snyder. 1974. Increased mortality of Cooper's hawks accustomed to man. Condor 76:215-216.

Speight, M.C.D. 1973. Outdoor recreation and its ecological effects: A bibliography and review. Univ. College of London, UK, Discuss. Pap. Conserv. 4. 35 pp.

Stalmaster, M.V. 1983. An energetics simulation model for managing wintering bald eagles. J.Wildl. Manage. 47:349-359.

Stalmaster, M.V. 1989. Effects of recreational activity on wintering bald eagles on the Skagit wild and scenic river system, Washington. Unpubl. rep., for Pacific Northwest Research Station, USDA, Forest Service. 796 pp. 
Stalmaster, M.V. and J.R. Newman. 1978. Behavioral responses of wintering bald eagles to human activity. J.Wildl. Manage. 42:506-513.

Stalmaster, M.V., J.L. Kaiser, and S.K. Skagen. 1993. Abstract: effects of recreational activity on feeding behavior of wintering bald eagles. J. Raptor. Res. 27:93.

Stangl, J.M. 1994. Effects of monitoring effort and recreation patterns on temporal and spatial activities of breeding bald eagles. M.S. Thesis, Montana State Univ., Bozeman. 74 pp.

Swenson, J.E. 1975. Ecology of the bald eagle and osprey in Yellowstone National Park. M.S. Thesis, Montana State Univ., Bozeman. 146 pp.

Swenson, J.E. 1979. Factors affecting status and reproduction of ospreys in Yellowstone National Park. J. Wildl. Manage. 43:595-601.

Swenson, J.E., K.L. Alt, and R.L. Eng. 1986. Ecology of bald eagles in the Greater Yellowstone Ecosystem. Wildl. Monogr. No. $95.46 \mathrm{pp}$.

USDI, Bureau of Land Management and USDA Forest Service. 1991. Snake River Activity/Operations Plan. $101 \mathrm{pp}$. + append. and maps.

Van Daele, L.J. and H.A. Van Daele, 1982. Factors affecting the productivity of ospreys nesting in westcentral Idaho. Condor 84:292-299.

Van der Zande, A.N. and T.J. Verstrael. 1984. Impacts of outdoor recreation upon nest-site choice and breeding success of the kestrel. Ardea 73:90-99.

Walters, C.J. and C.S. Holling. 1990. Large-scale management experiments and learning by doing. Ecology. 71:2,060-2,068.

Wasser, J.S. 1986. The relationship of energetics of falconiform birds to body mass and climate. Condor 88:57-62.

Watson, J.W. 1993. Responses of nesting bald eagles to helicopter surveys. Wildlife Soc. Bull. 21:171-178.

White, C.M. and T.L. Thurow. 1985. Reproduction of ferruginous hawks exposed to controlled disturbance. Condor 87:14-22.

Young, L.S. 1980. A quantitative evaluation of human disturbance impacts on the breeding ecology of bald eagles in the San Juan Islands, Washington. Report prepared for the Washington Dept. of Game, Olympia. 38 pp. 



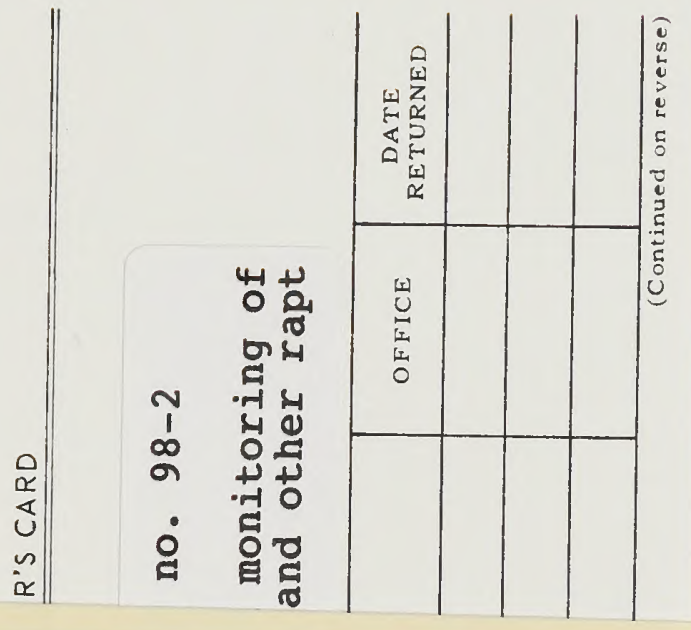

QL 84.2 .L352 no. 98-2 88055556

Inventory and monitoring of bald eagles and other rapt BLIVI LISKAMT BLDG 50, ST-150A DENVER FEDERAL CENTER P.O. BOX 25047 DENVEF, COLORADO 80225 


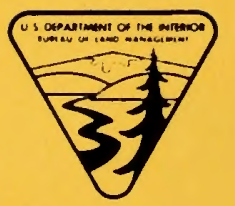

Bureau of Land Management

Idaho State Office

1387 S. Vinnell Way

Boise, Idaho 83709

BLM/ID/PT-98/005+1150 